\title{
Poverty Effects of Russia's WTO Accession: modeling "real" households and endogenous productivity effects
}

\author{
By \\ Thomas Rutherford, University of Colorado \\ David Tarr, The World Bank* \\ Oleksandr Shepotylo, University of Maryland
}

\begin{abstract}
We employ a computable general equilibrium comparative static model of the Russian economy to assess the impact of accession to the World Trade Organization (WTO) on income distribution and the poor. Our model is innovative in that we incorporate all 55,000 households from the Russian Household Budget Survey as "real" households in the model. This was accomplished due to our development of a new algorithm for solving general equilibrium models with a large number of agents. In addition, this is the first paper to include foreign direct investment and Dixit-Stiglitz endogenous productivity effects in trade and poverty analysis. In the medium term, we find that virtually all households gain from Russian WTO accession, with 99.9 percent of the estimated gains falling within a range between 2 and 25 percent increases in household income. We show that our estimates are decisively affected by liberalization of barriers against foreign direct investment in business services sectors and endogenous productivity effects in business services and goods. We use our integrated model to assess the error associated with a "top down" approach to micro-simulation. We find that approximation errors introduced by failing to account for income effects in the conventional sequential approach are very small. However, data reconciliation between the national accounts and the household budget survey is important to the results. Despite the estimated gains for virtually all households in the medium term, many households may lose in the short term due to the costs of transition. Thus, safety nets are crucial for the poorest members of society during the transition.
\end{abstract}

World Bank Policy Research Working Paper 3473, January 2005

The Policy Research Working Paper Series disseminates the findings of work in progress to encourage the exchange of ideas about development issues. An objective of the series is to get the findings out quickly, even if the presentations are less than fully polished. The papers carry the names of the authors and should be cited accordingly. The findings, interpretations, and conclusions expressed in this paper are entirely those of the authors. They do not necessarily represent the view of the World Bank, its Executive Directors, or the countries they represent. Policy Research Working Papers are available online at http://econ.worldbank.org.

"This work originated from a request by the Government of Russia to the World Bank for development of a methodology to assess the impact of WTO accession on poverty and social issues in Russia. We thank Jesper Jensen for help with this paper; Aleksander Ananjev, Mikhail Dmitriev, Glenn Harrison, Nanak Kakwani, Michael Lokshin, John Piggott, Guido Porto, Marcelo Olarreaga, Maurice Schiff, Radwan Shaban and L. Alan Winters for helpful comments; and Maria Kasilag for help with the logistics. We gratefully acknowledge financial support from the United Kingdom's Department for International Development (DFID) and the Research Committee of the World Bank under RF-P077820. 


\section{Household and Poverty Effects from Russia's Accession to the WTO}

\section{by}

\section{Thomas Rutherford and David Tarr}

\section{Introduction}

Among the most important policy changes that Russia may undertake in the near future are those that it will agree to as part of its accession to the World Trade Organization. Policymakers are concerned with not only the aggregate effects and impact on productive sectors of the economy, but the impact on the poor and other distributional effects now plays an important role in policy discussions in Russia. As a first step in that process, Jensen, Rutherford and Tarr (2004) have estimated the aggregate and sector impacts of WTO accession on Russia. In this paper, we extend that analysis and evaluate the impact of Russian accession to the WTO on the poor and the income and distributional effects more generally throughout the Russian population. We do so through the use of a computable general equilibrium model of the Russian economy with 55,000 "real household" agents integrated into the model. The agents are all the households of the Russian Household Budget Survey (HBS). Crucial to the results, the model also incorporates foreign direct investment in imperfectly competitive business service sectors with Dixit-Stiglitz endogenous productivity effects from variety in both business services and imperfectly competitive goods sectors.

Although interest in the impact of trade policy on poverty has dramatically increased in recent years, general equilibrium modeling with multiple representative households to examine equity issues dates back to Adelman and Robinson (1978). In recent years modelers employing this approach have focused more attention on the impact of trade policy on poverty, e.g. Harrison, Rutherford and Tarr (2003); Harrison, Rutherford, Tarr and Gurgel (forthcoming). These studies exemplify one approach, which is to include multiple households within the general equilibrium model. This is typically done by aggregating households from a household survey into 5-40 representative households. The major limitation of the multiple representative agent approach is that there can be large differences among the households in each representative household. It can be important, in formulating policy for poor households, to incorporate all the diverse information from a household budget survey. Consequently, in summarizing the state of the literature, Bourguignon and Perreira (2003, p.343) have argued that one of the major challenges for the 
analysis of the impact of economic policies on poverty and income distribution is to integrate a computable general equilibrium model with "real" households from the household survey rather than representative households, but they note that this is empirically difficult.

Given the difficulty in incorporating large household data sets as multiple agents of a computable general equilibrium (CGE) model, ${ }^{1}$ several authors (e.g., Bourguignon, de Melo and Morrison (1991), Chen and Ravallion (2004), Ravallion and Loshkin (2004)) have adopted a sequential (also called "open loop" or "top down") micro-simulation approach. In the first step a single representative agent computable general equilibrium model is employed to obtain the estimated price changes from a trade policy change. These price changes are then fed into a micro-simulation household model for predicted household effects. The sequential approach allows examination of the diversity of impacts across all the households in the household survey and is thus "a micro-simulation." But, in principle, the sequential approach suffers from two methodological problems. First, it ignores feedback effects of the quantity changes on the equilibrium prices in the general equilibrium model. Second, although efforts are sometimes made at data reconciliation, ${ }^{2}$ it does not require reconciliation of inconsistent information on household income from the national accounts (which report factor payments) and the household surveys (which report factor income). There is no assessment in the literature, however, of the magnitude of the errors in the estimates due to these two problems. If it is small, authors may use the simpler sequential approach to micro-simulation without significant bias.

In this paper we employ our integrated 55,000 "real" agent computable general equilibrium model to evaluate the magnitude of the errors from the two problems of the sequential micro-simulation approach. Key to solving this model is that we have developed a new algorithm for solving general equilibrium models that significantly improves on the Negishi algorithm for models with a very large number of consumer agents.

Regarding the two problems of the sequential or open loop approach, we find that, provided that data are reconciled, the bias from ignoring feedback effects on price determination is very small. It is possible with other data sets that the bias could be larger, but we find no significant difference in equilibrium market prices between our integrated approach and prices or welfare effects from the sequential approach.

\footnotetext{
${ }^{1}$ There have, however, been some unpublished papers where authors used constant returns to scale computable general equilibrium models and have incorporated a large number of households. G rtz, et al. (2000) and Cockburn (2001) employed models with about one and three thousand households, respectively; and Cororaton (2003) has a model for the Philippines with 24,000 households.

${ }^{2}$ Bourguignon et al. (2002) have developed a procedure for reconciling the micro results and the CGE model results regarding employment choices.
} 
On the other hand, data reconciliation results in important differences in estimated impacts across income groups. Moreover, the results from the integrated model approach are slightly progressive, i.e., poorer households gain more than the richer households, whereas, results from the sequential approach are slightly regressive. The difference regarding progressive or regressive results is not a general result, but is due to the specific data relevant to Russia, and the reasons are provided below. But a change in the qualitative assessment of whether WTO accession is progressive or regressive highlights the importance of data reconciliation issues. ${ }^{3}$

We incorporate foreign direct investment in business services with Dixit-Stiglitz variety effects in imperfectly competitive goods and services sectors. Then liberalization of barriers against FDI in services and tariff reduction in goods lead to endogenous productivity effects. Endogenous productivity effects from FDI in services has never been incorporated in trade and poverty analysis; ${ }^{4}$ consequently, we obtain significantly larger estimated gains for the average household compared with a constant returns to scale (CRTS) version of our model. We produce distributions of results over all 55,000 households for both our central model and the CRTS model. The two distributions of gains have a very small overlap in the tails, with the estimated gains for the vast majority of households in our central model exceeding the estimated gains for all households under a CRTS version of the model. This shows that although diversity of results across households is important to know distributional effects, the choice of model (i.e., FDI with endogenous productivity effects) dominates the absolute level of the estimated welfare results for households.

In order to obtain factor share information for the full dataset, we have also employed "small area estimation" and "matching" techniques to combine information from the Russian Longitudinal Monitoring Survey and the larger Russian Household Budget Survey.

The gains to Russia in our central model, averaged over all households, from WTO accession are 7.3 percent of Russian consumption (or 3.4 percent of GDP) in the medium run. We find that virtually all households obtain at least some increase in their income. The gains typically range from a minimum of about 2.0 percent increase in household income to about 25 percent. The lack of virtually any losers in our model at the micro level is explained by the fact that we

\footnotetext{
${ }^{3}$ Without data reconciliation the household model and the representative agent model can produce very different results. Ianchovichina and Martin (2004) estimated that China will gain from WTO accession based on their representative agent model. But Chen and Ravallion (2004) estimate overall losses for China from WTO accession based on their household model using price changes from Ianchovichina and Martin.

${ }^{4}$ Brown and Stern (2001) and Dee et al. (2003) have three sector multi-region models of trade with FDI in services; but endogenous productivity effects do not play a role in their results. Jensen, Rutherford and Tarr (2004) have a single representative consumer model where endogenous productivity effects from FDI in services play a crucial role in the results.
} 
incorporate foreign direct investment in services with endogenous productivity effects from services liberalization and from trade liberalization.

The CRTS version of our 55,000 agent model precludes the possibility of Dixit-Stiglitz variety gains. With this CRTS model, the distribution of gains has a mean of 1.2 percent of consumption (or 0.6 percent of GDP) and we estimate that seven percent of the households would experience losses. Thus, for about seven percent of the households, the sign of the impact of the policy change is altered. Thus, modeling foreign direct investment with endogenous productivity effects in business services and imperfectly competitive goods is crucial, not only to the magnitude of the average results, but also to the sign of the results for about seven percent of the households. .

We find that gains are rather evenly distributed across income groups, but we find that the poor gain slightly more than the wealthy because the wage rate of unskilled labor increases more than the rate of return on capital. We also find that rural households gain less than urban households because the wage rate of skilled labor increases more than the other factors of production and rural households are less endowed with skilled labor than urban households.

We decompose these overall gains into the sources. The gains from foreign direct investment (FDI) liberalization in services alone are 5.3 percent of the value of Russian consumption or more than 70 percent of the total value of the gains. We estimate that the welfare gains from Russia's tariff reduction are 1.3 percent of consumption and improved market access results in gains of 0.7 percent of consumption. Thus, while improving its offer to foreign services providers within the context of the GATS has been one of the most difficult aspects of Russia's negotiation for WTO accession, our estimates suggest that the most important component of WTO accession for Russia in terms of the welfare gains is liberalization of its barriers against FDI in services sectors.

Despite the significant gains we estimate, during a transition period it is possible that many households will lose. Displaced workers will have to find new employment. They will suffer losses from transitional unemployment and will likely incur expenses related to retraining or relocation. Some of the poorest members of the population are ill equipped to handle these transition costs. Thus, despite a likely substantial improvement in the standard of living for almost all Russians after adjustment to a new equilibrium after accession to the WTO, government safety nets are very important to help with the transition and especially for the poorest members of society. 
We describe the model, algorithm and data in sections II and III. Results are presented in section IV. In section V we assess the errors in a sequential approach. Results of our sensitivity analysis are shown in section VI.

\section{The Model and Algorithm}

We employ a small open economy computable general equilibrium model of the Russian economy with multiple households. In this paper we extend our earlier representative agent model of the Russian economy to a model with 55,098 households integrated into a single model. Since we have described the structure of the single representative agent model in Jensen, Rutherford and Tarr (2004), we only briefly describe the structure of the representative model here. Rather we focus on the features of the model that are necessary to generalize the model to 55,098 households. We then discuss household demand and the algorithm we have developed. We also briefly summarize some evidence of the importance of liberalization of barriers against foreign direct investment in services and the productivity impacts of greater variety of imported goods.

\section{Overview of the Model Formulation}

The key modeling features that distinguish this paper from previous applied general equilibrium modeling exercises linking trade and poverty is that we permit foreign direct investment in business services and additional varieties of business services endogenously increase the productivity of sectors using that service through the Dixit-Stiglitz variety effect (see Markusen, Rutherford and Tarr, 2000 for elaboration). We also allow for Dixit-Stiglitz productivity effects in goods, both for final consumers and for intermediate use, as explained in Ethier (1982). We shall show that these features have a fundamental effect on the results for the estimated impact of WTO accession on poverty in Russia.

There are 35 sectors in the model listed in table 1 . These sectors fall into three categories: competitive sectors producing goods and services; imperfectly competitive goods sectors; and imperfectly competitive services sectors. The structure of production is depicted in figure 1 .

Competitive Sectors. In competitive sectors price equals marginal costs and imports and domestic goods are differentiated (the Armington assumption). See de Melo and Tarr (1992) for a description of the details of how these sectors are modeled. 
Imperfectly Competitive Sectors. In imperfectly competitive goods sectors, goods are produced with a fixed cost and constant marginal costs. Foreign firms supply the Russian market with production facilities abroad. We assume symmetry among domestic firms as well as among foreign firms, but costs differ between domestic and foreign firms. We have firm level competition with pricing decisions based on large group monopolistic competition. The ratio of marginal costs to average costs is assumed fixed, which together with our pricing assumption, implies that output per firm is fixed. Both final and intermediate users of the output of imperfectly competitive sectors obtain a quality adjusted unit more cheaply when there are additional varieties via the Dixit-Stiglitz variety effect. Entry and exit is determined by a zero profit condition.

Business Services Sectors. Business services are supplied both by competitive firms on a cross-border basis and, since many services are more effectively supplied with a domestic presence, by imperfectly competitive firms (both multinational and Russian) that have a domestic presence in Russia. For imperfectly competitive firms the cost and pricing structure is similar to imperfective competitive goods producers except that production of service by multinational service providers is done in Russia. Multinational service providers will import some of their technology or management expertise when they decide to establish a domestic presence in Russia. Thus, their cost structure differs from Russian service providers. They incur costs related to both imported inputs and Russian primary factors, in addition to intermediate factor inputs. These services are characterized by firm-level product differentiation. Restrictions on foreign direct investment, right of establishment, the movement of business personnel, and lack of intellectual property protection and contract enforcement have major, direct impacts on multinational firms providing services to the market.

The number of multinational and Russian firms that are present in the Russian market depends on profitability in the Russian market. For multinational firms, the barriers to foreign direct investment affects the profitability. Reduction in the constraints on foreign direct investment will typically lead to productivity gains from the Dixit-Stiglitz variety effect because when more varieties of services are available, buyers can obtain varieties that more closely fit their demands and needs.

Primary Factors. Primary factors of production are capital, skilled and unskilled labor. There are five types of capital in the model: (1) mobile capital that can be used in any sector without adjustment costs (46\% of total capital); (2) sector-specific capital in the energy sectors, 
namely ownership of the mineral resources in oil extraction, gas and coalmining (representing 15 percent of total capital); (3) sector specific capital required for expansion of output in imperfectly competitive domestic firms producing either goods or services (representing 32 percent of the capital in the benchmark); (4) sector specific capital required for expansion of output in imperfectly competitive foreign firms producing either goods or services (representing 5 percent of the capital in the benchmark); and (5) ownership of licenses for monopoly rents in services sectors (representing 2 percent of capital in the benchmark). We do not have data that would allow us to associate specific capital holdings in given sectors with particular households. Thus, we assume that all households that hold capital, hold the different types of capital in the same proportions.

\section{Household Consumer Demand}

Based on the data work described below, we aggregate individuals within each of the 55,000 households to obtain household factor income shares, expenditure shares on the commodities in our model and transfers between the household and the government and savings. We assume each household maximizes a Cobb Douglas utility function of the aggregate 35 goods in our model subject to its budget constraint (which is factor income net of transfers). Each of the 35 aggregate commodities is a CES (“Armington") aggregate of imported goods or services and goods or services produced in Russia. In imperfectly competitive goods sectors, imported and Russian produced goods are Dixit Stiglitz aggregates of the outputs of foreign or Russian firms. (Since consumer demand is analogous to firm level demand, the structure is depicted in figure 1 under "composite intermediate IRTS goods.") The structure of consumer demand in imperfectly competitive services sectors (equivalent to business services in our model) is depicted on the left side of figure 1 under "Business Services." Competitively supplied cross-border services and imperfectly competitive services produced in Russia are a CES (Armington) aggregate. Services produced in Russia are a Dixit-Stiglitz aggregate of services provided by multinational service providers and Russian service providers. Given our elasticity assumptions, we have pure firm level product differentiation (no preferences for varieties according to country of origin) for all Dixit Stiglitz goods and services.

Consumer demand, as well as firm level demand, exhibits love of variety in imperfectly competitive goods. Given that we have weak separability and homothetic functions at all levels of consumer demand, the conditions for two-stage (or multi-stage budgeting) are satisfied. Given the initial data on each of the households, and our assumptions on the structure of demand, we solve for the parameter values in each of the 55,000 household utility functions that are consistent with 
optimization by the households. Thus, the demand functions of all households are dependent on their initial choices and, in general, differ from one another.

\section{Solving for a General Equilibrium with 55,000 Households}

Although the Negishi algorithm is a quite efficient algorithm for solving representative agent general equilibrium models, ${ }^{5}$ with 55,000 households it was necessary to devise a new algorithm that reduces the dimensionality of the problem. We illustrate the algorithm in the two commodity case in figure 2 . The key to the algorithm is that we set up a representative agent model where the representative agent has the same structure of demand as the households. In the initial equilibrium, we calibrate the preferences of the representative agent so that the quantities chosen by the representative agent are the same as the aggregate of the quantities chosen by the households. This is point $\mathrm{A}$ in figure 2A.The budget constraint of the representative agent is the aggregate budget constraint of the households, i.e., the sum of factor incomes net of transfers.

Now consider the counterfactual of WTO accession. Step 1 of our algorithm is analogous to the sequential or top down approach. In step 1, we first solve for the new equilibrium in our representative agent model. ${ }^{6}$ This is depicted as a shift from point $\mathrm{A}$ to point $\mathrm{B}$ in figure $2 \mathrm{~A}$. Budget constraint line $\mathrm{P}^{1} \mathrm{P}^{1}$ reflects an increase in factor incomes and a decline in the price of $\mathrm{X}$ relative to $\mathrm{Y}$. We then plug these prices into the household compensated demand functions of all 55,000 households to obtain the quantity demanded of all goods and services by all households at prices given by $\mathrm{P}^{1} \mathrm{P}^{1}$. Since we use compensated household demand functions for each good, summing quantities demanded over all households gives a point on the aggregate budget constraint $\mathrm{P}^{1} \mathrm{P}^{1}$. This is depicted as point $\mathrm{C}$ in figure $2 \mathrm{~A}$.

In step 2 of the algorithm, we first recalibrate the preferences of the representative consumer so that the choices of the representative consumer are consistent with the aggregated choices of the real households. This is shown as point $\mathrm{C}$ in figure $2 \mathrm{~B}$. (We do not recalibrate preferences of any of the real households.) Point $\mathrm{C}$ is not an equilibrium since, despite the fact that the representative agent and households are in equilibrium, with prices $\mathrm{P}^{1} \mathrm{P}^{1}$ firms will only supply quantities at point $\mathrm{B}$. In figure $2 \mathrm{~B}$, we have drawn in the production possibility frontier, which illustrates that point $\mathrm{C}$ is not an equilibrium for firms. Consequently, we solve the representative agent model again (this time with the new preferences of the representative agent) for an equilibrium of the representative agent model. This is shown as point $\mathrm{D}$ in figure $2 \mathrm{~B}$ with

\footnotetext{
${ }^{5}$ See Rutherford (1999b) for a description of the Negishi algorithm.

${ }^{6}$ We use the MPSGE subsystem of GAMS to solve the representative agent model. See Rutherford (1999a).
} 
budget constraint $\mathrm{P}^{2} \mathrm{P}^{2}$. Analogous to step 1, we then feed the new prices of the equilibrium of the representative agent model into the household compensated demand functions to determine the new quantities demanded. These steps are repeated until the norm of the difference between the vector of prices in the current and previous steps is below a pre-specified level.

There are two points we emphasize about the algorithm. First, we have not solved the household demand functions simultaneously. We have only evaluated them at each step of the algorithm. This is the key to reducing the dimensionality of the problem. Second, only the first step involves an exogenous shift in the parameters of the model. As a result, most of the price change occurs in the first step of the algorithm. Price changes in subsequent steps are very small (we quantify this below) and, as a result, the algorithm converges rapidly.

\section{Evidence on the Productivity Impact of Liberalization of Barriers Against Foreign Direct Investment in Services and on Goods}

Services Sector Liberalization. A growing body of evidence and economic theory suggests that the close availability of a diverse set of business services is important for economic growth. The key idea is that a diverse set (or higher quality set) of business services allows users to purchase a quality adjusted unit of business services at lower cost. As early as the $1960 \mathrm{~s}$, the urban and regional economics literature argued that non-tradable intermediate goods (primarily producer services produced under conditions of increasing returns to scale) are an important source of agglomeration externalities which account for the formation of cities and industrial complexes, and account for differences in economic performance across regions. The more recent economic geography literature (e.g., Fujita, Krugman and Venables, 1999) has also focused on the fact that related economic activity is economically concentrated due to agglomeration externalities (e.g., computer businesses in Silicon Valley, ceramic tiles in Sassuolo, Italy). Evidence comes from a variety of sources. Ciccone and Hall (1996) show that firms operating in economically dense areas are more productive than firms operating in relative isolation. Hummels (1995) shows that most of the richest countries in the world are clustered in relatively small regions of Europe, North America and East Asia, while the poor countries are spread around the rest of the world. He argues this is partly explained by transportation costs for inputs since it is more expensive to buy specialized inputs in countries that are far away for the countries where a large variety of such inputs are located. Marshall (1988) shows that in three regions in the United Kingdom (Birmingham, Leeds and Manchester) almost 80 percent of the services purchased by manufacturers were bought from suppliers within the same region. He cites studies which show that firm performance is enhanced by the local 
availability of producer services. In developing countries, McKee (1988) argues that the local availability of producer services is very important for the development of leading industrial sectors.

Productivity Effects from Goods Liberalization. As Romer (1994) has argued, product variety is a crucial and often overlooked source of gains to the economy from trade liberalization. In our model, it is greater availability of varieties that is the engine of productivity growth, but we believe there are other mechanisms as well through which trade may increase productivity. ${ }^{7}$ Consequently, we take variety as a metaphor for the various ways increased trade can increase productivity. Winters et al. (2004) summarize the empirical literature by concluding that "the recent empirical evidence seems to suggest that openness and trade liberalization have a strong influence on productivity and its rate of change." Some of the key articles regarding product variety are the following. Broda and Weinstein find that increased product variety contributes to a fall of 1.2 percent per year in the "true" import price index. Hummels and Klenow (2002) and Schott (forthcoming) have shown that product variety and quality are important in explaining trade between nations. Feenstra et al. (1999) show that increased variety of exports in a sector increase total factor productivity in most manufacturing sectors in Taiwan (China) and Korea, and they have some evidence that increased input variety also increases total factor productivity. Finally, Feenstra and Kee (2004) show the export variety and productivity of a country are positively correlated.

\section{Data}

In Jensen, Rutherford and Tarr (2004) we explain how we disaggregated the official Russian input-output table, how we calculated Russian tariff and export tax rates. Here we focus on the features of the model relevant to development of the multi-household model. In addition, given its importance to the results, we briefly explain how we estimated the barriers to foreign direct investment.

\footnotetext{
${ }^{7}$ Trade liberalization may induce firms to move down their average cost curves, or import higher quality products or shift production to more efficient firms within an industry. Tybout and Westbrook (1995) find evidence of this latter type of rationalization for Mexican manufacturing firms.
} 


\section{Households}

Households are modeled endogenously based on the 55,000 households of the Russian Household Budget Survey (HBS). The HBS, which is representative at the regional level, has very detailed information on household consumption expenditures, and information about age, gender, education, and occupation of each member of the household. It also has information about expenditures and savings and by implication household income.

The major shortcoming of the HBS for our purposes is that it does not contain information on the sources of income of the households. For sources of household income, we must turn to the Russian Longitudinal Monitoring Survey (RLMS). The RMLS has less than 5,000 observations and is not representative of the population on the regional level. But is has extensive information on individual and household sources of income: wages and profits from first, second, third jobs; pensions and unemployment benefits; profits and dividends from accumulated assets.

We have employed both small area estimation (SAE) and Matching techniques (see Elbers et al., 2003; Rao, 1999; Moriarity and Scheuren, 2003) to generate sources of income data for all 55,000 plus households in the HBS. We describe our procedures in Appendix A. Results from both techniques yield similar results.

The key point is that we chose characteristics of the two datasets that are common to both datasets and which we expect influence factor shares of income. These characteristics, which can be found in both the HBS and the RLMS, are:

- Personal characteristics: age, gender, skilled or unskilled worker, head of the household, primary, secondary, and other occupation, and income.

- Household characteristics: family size, members of the household who work, gender of head of household

- Geographic characteristics of the locality: region of Russia, urban or rural..

In the SAE procedure, using the RLMS data, we then estimate regression equations where the independent variables are those listed above and factor shares are the dependent variables. We assume that the estimated equations based on the RLMS data apply to all the households in the HBS. Using the data on the household characteristics in the HBS, we thereby generate factor shares for the larger HBS. Factor shares and consumption shares aggregated to deciles are presented in tables 3 and 4 . 


\section{Reconciliation of the National Account and Household Budget Survey Data}

We have two sources of data for aggregate factor incomes: data from National Accounts and data from the HBS. In our Russian data, capital's share of factor income is much larger in the National Account data than in the HBS (see table 1). This is typical. Ivanic [2004] mapped income from the Living Standards Measurement Surveys (LSMS) surveys in 14 countries into factor shares and compared factor shares with the input-output tables in these countries. Capital's share from the LSMS surveys was $21 \%$ of household income, but it was $52 \%$ of household income based on National Account information (based on the "GTAP" data set).

We must produce a balanced Social Accounting Matrix in order to implement our integrated model, which means we must reconcile those differences. There are biases in both the collection of National Account and Household Survey data so that neither source is clearly correct. A key problem with the factor share data from the national accounts is that capital's share is calculated residually in the input-output tables. Then in sectors where labor payments are underreported, the share of capital is biased up. On the other hand, income estimates from LSMS surveys are known to be less than income estimates from National Accounts. Deaton (2003) explains that one of the most likely explanations of the difference is that households fail to respond to the survey, and that the probability of non-response plausibly increases monotonically with income. This presumed pattern of non-response to the household survey would also help explain this difference in capital's share, since the rich are likely to have more capital than the poor.

We took total value added by sector from the National Accounts, but given our desire to preserve "real households" and our focus on poverty, we did not want to alter the HBS factor shares. Thus, we did not alter the HBS data or value-added data by industry from the National Accounts. Rather we adjusted factor shares at the industry level to be consistent with the factor payments implied by the HBS. This reconciliation of the two sets of data significantly decreased the share of capital reportedly paid by firms, especially in some of the more capital intensive sectors like ferrous and non-ferrous metals (see table 1).

\section{Barriers to Foreign Direct Investment in Services Sectors.}

In order to estimate the ad valorem equivalence of barriers to foreign direct investment, we first commissioned surveys in telecommunications; banking, insurance and securities; and maritime and air transportation services by Russian research institutes that specialize in these 
sectors. Using these surveys as well as supplementary data, Kimura, Ando and Fujii ${ }^{8}$ employed methodology and estimates explained in the volume by C. Findlay and T. Warren (2000) to estimate the barriers to FDI.

For each of these service sectors, authors in the Findlay and Warren volume evaluated the regulatory environment across many countries; the same regulatory criteria were assessed for all countries in a particular service sector. The price of services is then regressed against the regulatory barriers to determine the impact of any of the regulatory barriers on the price of services. Assuming that the international regression applies to Russia and assessing the regulatory environment based on the surveys, Kimura, Ando and Fujii estimated the ad valorem impact of a reduction in barriers to foreign direct investment in these services sectors. The results are in table 2.

\section{Estimated Impacts of Russian WTO Accession}

\section{What is the Counterfactual?}

In our general WTO scenario, we assume: (1) that barriers against foreign direct investment are reduced as indicated in table 2; (2) seven sectors subject to antidumping actions in export markets receive slightly improved market access. This is implemented as an exogenous increase in their export price as shown in table 2; and (3) the tariff rates of all sectors are reduced by fifty percent. Unless otherwise stated, we assume that the government employs lump sum distributions or taxes households in equal percentages of household income so that government revenue remains unchanged. In one scenario (column two of table 5), we assume that government distributions are in equal absolute amounts. We also conduct simulations to assess the relative importance of the three changes we implement. In columns three, four and five of table 5, we decompose the WTO scenario into the separate impact of (1) FDI liberalization; (2) improved market access; and (3) tariff liberalization.

\section{Aggregate Results in the Full 55,000 Household Model}

Aggregate results are summarized in table 5. Welfare results in table 5 are obtained by aggregating the equivalent variation gains (as a percent of consumption) of the 55 thousand consumers. ${ }^{9}$ For our general WTO scenario (column 1), we obtain rather substantial aggregate

\footnotetext{
8 The three papers by Kimura, Ando and Fujii as well as the underlying questionnaires are available at www.worldbank.org/trade/russia-wto.

${ }^{9}$ The equivalent variation of each household is weighted by its share of base year expenditures.
} 
gains for a comparative state trade model equal to 7.3 percent of aggregate consumption. ${ }^{10}$ The main driving force for this result is that the reduction of the barriers against foreign direct investment. Reduction of barriers against multinational service providers or foreign goods producers increases the (tariff ridden) demand curve for multinational services or foreign goods. In imperfectly competitive sectors, this induces entry of new multinational service providers or new varieties of foreign goods until zero profit is restored. Although there is a reduction in domestic varieties, there is a net increase in varieties. The increase in varieties lowers the quality adjusted cost of purchasing the services or goods in downstream industries, and this acts like an externality that increases the total factor productivity in the downstream using sectors.

If we assume constant returns to scale in all sectors of the economy, the estimated gains (column 6) are reduced to 1.2 percent of consumption. These results show that incorporating liberalization of barriers to foreign direct investment in the analysis as well as the Dixit-StiglitzEthier formulation for endogenous productivity effects are both crucial in explaining the rather substantial estimated gains from Russian WTO accession.

The results for the decomposition of effects are shown in columns three, four and five. The key result is that liberalization of barriers to foreign direct investment is responsible for an estimated welfare gain of 5.3 percent of consumption, or over 70 percent of the total welfare gain. Given that our estimates are that barriers against FDI in services are much higher than tariff barriers and that there will be only small gains in market access the relative importance of liberalization of barriers to FDI is not surprising. In column 7 we also show the results of our estimates of the impact of only a fifty percent reduction in the barriers to FDI, along with the same improved market access and tariff reduction that we implement in our WTO scenario. The gains are reduced to 4.1 percent of consumption; the gains remain substantial, but significantly reduced due to a less significant reduction in FDI barriers.

Since households can not change their factor endowments between unskilled labor, skilled labor and capital, but they can substitute among commodities consumed, impacts on factor incomes through changes in factor prices tend to dominate the welfare impacts in these kinds of models. ${ }^{11}$ In the WTO scenario, the wage rate of skilled labor increases by 5.3 percent, the wage rate of unskilled labor increases by 3.7 percent and the return on capital increases by 1.8 percent. Although the return to capital rises relative to a basket of consumption goods, it does not rise as much as wages. The return to capital increases less than wages because owners of "specific

\footnotetext{
${ }^{10}$ Computable general equilibrium evaluations of trade policy changes typically estimate gains of less than one percent of GDP. See Rutherford and Tarr (2002) for a discussion and several key examples.

11 See, for example, Harrison, Rutherford and Tarr (2003).
} 
capital" in imperfectly competitive sectors that are subject to increased competition from imports or from foreign direct investment will see a reduction in the value of their returns. Returns to mobile capital increase by over six percent, even faster than returns to skilled labor because the economy shifts resources into the more capital intensive sectors and away from more unskilled labor intensive sectors such as light industry and mechanical engineering and metal working (see table 6). But, the return on sector specific capital in all imperfectly competitive sectors falls, so that the total return on capital rises less than wages. The ratio of skilled to unskilled labor in the expanding sectors in greater than in the contracting sectors. As a result, the wage of skilled labor rises faster than the wage rate of unskilled labor. ${ }^{12}$

\section{Results Aggregated to the Decile Level}

In order to ascertain broad patterns and the impact of WTO accession on the poor, we have separated the 55,000 households into ten deciles, with ten percent of the households in each. Households are ranked according to per capita income with decile 1 comprising the poorest ten percent of the households, decile 10 the richest ten percent and so on. We run the model with all 55,000 households. Then we have aggregated the equivalent variation gains (as a percent of consumption) of the households in each decile and presented those results in table 7 . We also present in table 7 the aggregated results for rural and urban households in each decile. We believe that the distributional consequences on the poor are more transparent when the results are presented in this manner.

We see that all ten representative households gain significantly, but in column one the richest household gains slightly less in percentage terms than the wealthy. This is because the return on capital increases less than the wage rate of unskilled labor. From table 3 we can see that the rich depend more on earnings from capital than the rest of the population, so the impact on their income is affected more by the relatively lower increase in the returns to capital. ${ }^{13}$ Skilled labor is more evenly distributed across income deciles, reflecting that fact that government

12 The data do not allow us to distinguish capital holdings at the household level between the various types of capital. Thus, all households are assumed to hold the five kinds of capital in our model in equal proportions. Households that depend disproportionately on specific capital that falls in return would be expected to lose from WTO accession.

${ }^{13}$ Household income in Russia exceeds household consumption for almost all households. The reason is that Russian has a large current account surplus. Consistency between the macro balances and the household data in construction of the Social Accounting Matrix implies that household factor income must be larger than household consumption for most households to allow for the transfer of capital to foreigners as well as to pay for investment. It follows that the change in factor income as a percent of consumption will be larger than the change in factor income as a percent of household income. 
employees such as researchers and teachers often receive very low wages, and that retirees living only a pension are often retired skilled workers. ${ }^{14}$

Rural households typically gain less than urban households. This is due to the fact that rural households have less education and are therefore classified as less skilled than urban workers in the same income group, and unskilled worker wages do not increase as much as skilled worker wages.

We hold expenditures of the government constant in our model and require that any change in government revenue be offset by either a tax on households for a decline in government revenue or a transfer to households if a surplus appears. In the case of WTO accession of Russia, government revenue increases despite a loss of about 33 percent of the tariff revenue of the government. This is because collected tariff revenue in Russia is only about 1.6 percent of GDP. Although tariff revenue falls to about 0.9 percent of GDP, the economy grows as a result of WTO accession so the other indirect taxes of the government more than offset the loss of tariff revenue.

Our central assumption is that the surplus is distributed to all households in proportion to their income. Then each household will gain about 1.5 percent of its income from this transfer. Proportional government transfers imply larger absolute transfers to wealthier households. On equity grounds, many would prefer a distribution scheme that is more progressive. Consequently, we also assess the impact of fixed and equal absolute transfers to all households and present those results in column 2 of tables 5 and 7. Absolute transfers are progressive and will result in the poor doing significantly better than the richer households.

Below we show that virtually all the change in income for any of the deciles of aggregated households is due to changes in the income sources, that is, changes in the prices of factors of production and transfers. The effects on the welfare at the level of deciles of aggregated results due to price changes varies from 0.3 percent to -0.3 percent. On the other hand, the effects on the welfare of the deciles due to factor income changes varies from 8.3 percent to 6.7 percent. There are individual households for which the prices of goods are more important, but these households are not common.

\section{Results for Individual Households}

Distribution of the Results. The distribution of gains from Russian WTO accession across all 55,000 households is summarized in figure 3 . We also display in figure 3 , the

14 An individual is classified as skilled if he or she has any education post-high school. We defined skills at the individual level. We define labor and capital shares individually, and then aggregated factor shares within the household. 
distribution of gains for the poorest 13,775 households. Figure 3 shows there is a distribution of income changes across the 55,000 households that is centered around a mean gain of income of 7.3 percent. ${ }^{15}$ As is evident from figure 3 , we estimate that virtually all households will gain in the new equilibrium relative to the status quo. The distribution of gains for the poorest 25 percent of the population is comparable, although the mean of the gains is slightly larger, i.e., slightly progressive effects.

In figure 4 we compare the results across 55,000 households based on two models. On the right side of the diagram, is the histogram of results for all households from our central model. Despite diversity among households, virtually none are estimated to lose. ${ }^{16}$ On the left side of the diagram, we present the histogram of results for all households with a constant returns to scale model. The CRTS distribution is centered around 1.2 percent of gains in consumption and about seven percent of the households are estimated to lose from accession to the WTO.

The striking aspect of figure 4 is that the distribution of gains from our central model is centered sufficiently far to the right of the CRTS distribution that there is overlap of the two distributions only in the tails. This figure emphasizes that getting the underlying model right dominates the impact of household diversity on the absolute level of the estimated impacts on the household. It is evident that incorporating foreign direct investment liberalization and endogenous productivity effects will decisively affect the results; in our case, for a nontrivial share of the population even the sign of the impact changes. Nonetheless, diversity of impacts is important because within either model, there is a wide range of impacts.

To put these numbers in perspective, Rutherford and Tarr (2002) have analytically derived the relationship between a permanent increase in the steady state growth rate and equivalent variation. A welfare gain of 10 percent of consumption corresponds to a permanent increase in the growth rate of about 0.4 percent. Although cross country assessments of the impact of trade liberalization of growth have been criticized, several authors have estimated that trade liberalization could increase the growth rate by between one and 2.5 percent. ${ }^{17}$

15 In order not to distort the figure, we exclude 14 households with estimated losses and seven households with estimated gains exceeding 25 percent (i.e., two-hundredths of one percent of the households are estimated to lose). Of the 55,098 households, there are 59 with gains less than two percent and 7 households with gains above 25 percent. Thus 99.9 percent of all households have gains that fall in the range of 2 to 25 percent.

${ }^{16}$ It is likely that many households that are heavily endowed with specific capital in declining sectors will lose from WTO accession. But those who can form joint ventures with foreign investors will likely see the value of their specific capital holdings increase. Our data, however, do not allow us to distinguish different types of capital holdings.

${ }^{17}$ One criticism of these regressions is that trade liberalization is often accompanied by macro stabilization, institutional reforms and other market reforms, and the trade liberalization variable in the cross country regressions may be picking up these other effects. But WTO accession involves a range of reforms, 
Regression Results. We follow previous authors (e.g., Chen and Ravallion, 2004) and regress equivalent variation gains produced by the model on individual, household, and regional characteristics. We caution, however, that the "independent" variables in the regression are not truly explanatory variables. That is, the dependent variable, equivalent variation, is obtained from model simulations, as opposed to an historical data set. Variables like region or gender are right hand side variables, but we do not have male and female wages separated in our model, nor do we have prices differing across regions. Consequently, these variables will influence equivalent variation in the regression only to the extent that they are correlated with variables in our model. Factor shares are the primary variables that explain differences across households, and many of these other "independent" variables are correlated with factor shares.

The equation we estimate is:

$$
\begin{aligned}
& \text { EVgains }_{i}=a_{0}+\sum_{k=1}^{2} b_{k} * \text { ind_charachteristic }{ }_{i k}+\sum_{k=1}^{3} c_{k} * \text { household_characteristic }_{i k}+ \\
& \sum_{k=1}^{7} d_{k} * \text { regional_characteristics }{ }_{j k}+\varepsilon_{i j}
\end{aligned}
$$

where $\mathrm{i}$ is a household ID and $\mathrm{j}$ is a regional ID. We define ind-characteristic as either age or gender of the head of household; household and regional characteristics are explained in table 8 along with results. We further assume that:

$$
\varepsilon_{i j}=\bar{w}_{j}+u_{i}
$$

where $\mathrm{i}$ is a household and $\mathrm{j}$ is a region and EV gains are the percentage gains in EV of the household as a percentage of consumption.

We run an ordinary least squares regression with robust standard errors clustered by localities for the 55,098 sampled households. We also run the same regression for the sub samples of the survey by dividing the households into quintiles according to per capita income.

Region results are compared to the Moscow-Saint Petersburg region and factor share results are compared with households whose income is derived from capital only. The estimated welfare gain is larger (statistically significant) for households that are headed by younger or female workers, with a higher percentage of skilled or unskilled labor relative to capital and who live in the Moscow-Saint Petersburg region relative to the North Caucusian, Ural or a few other

including institutional reforms necessary to accompany FDI liberalization, and trade liberalization may be a sine qua non of the overall reform process, because other interventions such as state subsidies often are unsustainable in an open economy. 
regions (although all regions gain), and urban households fare better than rural households. The household with all unskilled worker factor incomes gains 3.19 percent more compared with the household whose income is derived from capital only.

\section{How Significant Are the Biases from a Sequential (or Open Loop) Approach to Micro-Simulation Trade and Poverty Analysis?}

In this section, we evaluate the two approximation errors the sequential approach. We also evaluate the bias of aggregating households in deciles prior to running the model on the welfare results at the level of deciles of the population.

First, the sequential approach ignores quantity feedback effects from the household model on the determination of prices in the general equilibrium model. That is, in response to a the new set of prices fed into the household model, optimization by households would result in a different set of quantities. Due to the new quantity decisions by households, summing these quantities across households will yield aggregate quantities demanded for goods that are inconsistent with market equilibrium at the set of prices fed into the household model (illustrated by the difference between points $\mathrm{C}$ and $\mathrm{D}$ in figure 2). On the other hand, in an integrated approach, the quantity decisions by households are consistent with supply-demand balance for all markets at an equilibrium set of prices.

Unless there is a Social Accounting Matrix that integrates the households and the productive sectors of the economy, there is no consistency imposed between the data in the micro-simulation model and the general equilibrium model. Thus, in general, aggregate earnings of the households from skilled labor, unskilled labor and capital based in the household surveys need not equal to the payments to labor and capital reported by industries, and which are part of input-output tables for example. Sequential approaches often do not fully reconcile the inconsistent data.

\section{The Impact of Ignoring Quantity Feedback Effects is Negligible Provided Data are Reconciled}

We estimate that the bias from ignoring the quantity feedback effects on prices is very small. We have estimated the price changes for each sector in our model based on a top down approach or sequential approach and compared these price changes with the estimated price changes from our integrated (or bottom up) model. The price changes in the sequential approach are based on the price changes in a single representative consumer model. We have examined the 
price changes in two versions of the representative consumer model: one in which we have reconciled the macro data with the household budget survey in an integrated Social Accounting Matrix; and one representative agent model in which we have not reconciled the data. Comparison of the price changes between the representative agent model and the integrated model across the 35 sectors of our model depends crucially on whether we first reconciled the data. If the data are reconciled, the estimated price changes due to WTO accession in Russia are extremely close between the two models. With reconciled data, in 33 of the 35 sectors, the predicted price changes from the two models are within one percent of each other. ${ }^{18}$ On the other hand, with un-reconciled data sets, the estimated price changes from the representative agent and integrated models at the level of the sectors differ quite significantly in many cases, with an average difference of 23 percent. To take a typical example, in non-ferrous metals, the price is predicted to increase by 3.32 percent relative to our numeraire in the representative agent model with reconciled data, by 3.33 percent in the integrated model, but by 2.87 percent in the representative agent model with un-reconciled data. i.e., the price predicted price changes are within 0.3 percent of each other with reconciled data, but differ by 16 percent with un-reconciled data. .

We conclude that, provided the macro and household data are reconciled into a Social Accounting Matrix, price changes from a representative agent model and integrated model are likely to be close approximations for each other. The intuition for this is that the big increase in prices comes from the exogenous shock (movement from A to B in figure 2A). Feedback effects on prices from the quantity changes in a household model (movement from $\mathrm{C}$ to $\mathrm{D}$ in figure $2 \mathrm{~B}$ ) tend to be much smaller since there are no exogenous shocks.

\section{Data Reconciliation Has an Important Impact on the Results}

In table 9, we compare the household welfare results at the decile level of a sequential or integrated approach. The results for the integrated approach are from our model, with data reconciled; these results are identical at the decile level to the results in table 7 labeled "combined." That is, we run an integrated model with all 55,000 households. Then we have aggregated the equivalent variation gains (as a percent of consumption) of the households in each decile and presented those results. For the sequential approach, we do not reconcile the data. We run a single representative consumer model based on the input-output table and other macro data. This provides us with price changes for goods and factors, which we feed into the household

${ }^{18}$ In mechanical engineering the predited changes are very small in both models, 0.1 percent when rounded, but depart from each other by 33 percent. 
model for the determination of household equivalent variation of the 55,000 households. Aggregation of the household welfare results for households within each decile provides the results at the decile level in table 9.

The aggregated results for each decile show some significant differences. Moreover, the results from the integrated model approach are slightly progressive, i.e., poorer households gain more than the richer households. On the other hand, results from the sequential approach are slightly regressive.

The difference regarding progressive or regressive results is not a general result, but is due to the specific data relevant to Russia. It is explained as follows. The data in table one for Russia is typical of household budget surveys compared with input output tables--the share of capital in factor earnings is significantly smaller with household budget surveys. Since we are focusing on poverty and household effects, we choose "real households," i.e., we preserved the household data and adjusted the factor shares in the input output table to be consistent with the factor shares in the household budget survey. As a result of this reconciliation, several sectors are significantly less capital intensive in our reconciled data set. Notable among them are ferrous metals, non-ferrous metals and chemicals. But these are three of the sectors that expand the most due to WTO accession since they are export intensive and benefit the most from the real exchange rate depreciation. When these sectors expand, in the reconciled data set they do not increase the demand for capital relative to labor, but in the un-reconciled data set they do. Consequently the return to capital rises much more in the model with the un-reconciled data set, i.e., the sequential approach.

Finally, the table decomposes the impact of Russian WTO accession into the changes in factor prices, goods prices and taxes and transfers. For reasons explained above, all the deciles of aggregated households the impact of goods prices is relatively unimportant compared with the impact of factor prices.

\section{Does the Order of Aggregation or number of Households matter?}

Suppose we are interested in welfare results for representative households at the decile level. The theoretically correct way to evaluate this is to run the model with 55,000 households and then aggregate the households results. This allows for household demand diversity to be reflected in the determination of prices. Alternatively, we could aggregate households first, but this would, in principle, be biased since consumer diversity is not reflected in price determination.

In table 10 we present results based on four different aggregations of the household budget survey data. For $\mathrm{N}=10,70$ or 950 , we first aggregate the households into 10,70 or 950 
representative households. In all four cases we reconcile the macro data with the household budget survey. We then run the four versions of the model. Results for $\mathrm{N}=10$ are reported simply as the results for the representative household in the model. For the three versions of the model with more than ten households, the reported results are a weighted average of the welfare results for the individual households in the decile. It is evident from the table that the results are only negligibly affected by the order of aggregation at the decile level. That is, if we are interested in results at the decile level, running a model with more than ten households does not appear to make much difference.

On the other hand, there are individual households within each decile for which the results differ significantly. If we start with a model where we aggreagate the household budget survey to ten or twenty households, we miss the diversity of results from a micro-simulation model that may be important in identifying impacts on the poor. So, there is significant value in a micro-simulation model even aggregated impacts are small.

\section{Sensitivity Analysis}

The results depend on the choice of parameters in the model. In this section, we evaluate the impact on the results of the changing the values of the key parameters. We begin with "piecemeal sensitivity" analysis on the parameters. Then we discuss the results of our "systematic sensitivity" analysis.

\section{Piecemeal Sensitivity Analysis}

In table 11 we present the impact on welfare of varying the value of key parameters. In these scenarios, we retain the central value of all parameters except the parameter in question. In general, the gains to the economy (welfare gains) increase with an increase in elasticities, since higher elasticities imply that the economy is able to more easily shift to sectors or products that are cheaper after trade and FDI liberalization. ${ }^{19}$ There are three parameters in the table that have a strong impact on the results: the elasticity of substitution between value-added and business services (esubs); the elasticity of multinational firm supply (etaf); and theta fdi(i), the share of output of service sector i captured by multinational firms in the benchmark equilibrium. A

\footnotetext{
${ }^{19}$ An increase in the elasticity of substitution between varieties reduces the welfare gain. This is because when varieties are good substitutes, additional varieties are worth less to firms and consumers.
} 
liberalization of the barriers to FDI will result in a reduction in the cost of business services, both from the direct effect of lowering the costs of doing business for multinational service providers and from the indirect effect that additional varieties of business services allow users to purchase a quality adjusted unit of services at less cost. When the elasticity of substitution between valueadded and business services is high, users have the greater potential to substitute the cheaper business services and this increases productivity. And when the initial multinational share, theta fdi(i), is larger the same percentage increase in multinational varieties is a larger number of varieties. The elasticity of multinational and Russian firm supply (etaf, etad) is primarily dependent on the sector specific factor for each firm type (foreign or domestic). When etaf is high, a reduction in the barriers to foreign direct investment results in a larger expansion in the number of multinational firms supplying the Russian market, and hence more gains from additional varieties of business services. In addition, the share of the services market captured by multinationals has a strong effect, since a liberalization results in a larger number of new varieties introduced.

\section{Systematic Sensitivity Analysis}

Piecemeal sensitivity analysis shows how the results change when we vary the value of key parameters one-by-one, with central values of all parameters except the one under consideration. In the systematic sensitivity analysis, we allow all parameters to change simultaneously. A probability distribution for each parameter is chosen. We typically choose uniform probability distributions, with the lower and upper bounds for the values of the parameters taken from the lower and upper values of the key parameters presented in table 11 . We furthermore assume that all distributions are stochastically independent.

We have executed the model with all 55,000 households 7,500 times. ${ }^{20}$ Each time the program chooses a random configuration of parameters and executes the model with this

\footnotetext{
${ }^{20}$ We are continuing with the SSA until the sample distribution is "smooth." But we do not expect the qualitative results to significantly change.
} 
configuration. For each variable in our model, we then harvest the sample distribution based on the 7,500 solutions. Consequently the sample distribution is not dependent on any particular set of parameter values, but represents results representative of the full distribution of parameter values.

We present the distribution of the results in figure 5 for the poorest and richest deciles of the population. Results for each decile are the aggregated equivalent variations, as a percent of consumption, for the households in the decile. The top panel of figure 5 shows that the welfare gains as a percent of consumption for the poorest decile of the population are, in most cases, between $5 \%$ and $10 \%$; a 95 percent confidence interval is $6.1 \%$ to $9 \%$. For the richest decile, the gains are slightly smaller; a 95 percent confidence interval for the richest decile of the population is $5.1 \%$ to $8.3 \%$. These results are consistent with the central parameter value estimates, where we had the poorest decile gaining $7.6 \%$ and the richest $6.8 \%$. The bottom panel of figure 5 shows the corresponding cumulative distribution function of the welfare gains.

\section{Conclusions}

We estimate that in the medium term, virtually all households will gain from Russian WTO accession. We have shown that our estimates of the distribution of gains across the 55,000 households are decisively affected the inclusion of liberalization of barriers against foreign direct investment in business services sectors and endogenous productivity effects in business services and goods.

We find that errors in the estimates from failure to incorporate price feedback effects in a sequential, or top down, approach are very small if the data are reconciled between the national accounts and the household budget survey. But data reconciliation between the national accounts and the household budget survey is important to the results. This suggests that if the data are reconciled, the sequential approach may be a good approximation for an integrated model. The modeling choice regarding FDI and endogenous productivity effects appears much more important to the estimated household impacts.

Although not part of our model, we emphasize that during a transition period it is likely that many households will lose. There will be displaced workers who will have to find new employment. They will suffer losses from transitional unemployment and will likely incur 
expenses related to retraining or relocation. Thus, despite a likely substantial improvement in the standard of living for almost all Russians after adjustment to a new equilibrium after accession to the WTO, government safety nets are very important to help with the transition and especially for the poorest members of society who can ill afford a harsh transition. 


\section{References}

Adelman, Irma, and Robinson (1978), Sherman, Income Distribution Policies in Developing Countries, Stanford: Stanford University Press.

Bourguignon, Francois, Jaime de Melo and C. Morrison (1991), "Poverty and Income Distribution During Adjustment: Issues and Evidence from the OECD Project," World Development 19(1), 1485-1508.

Bourguignon, Francois and Luis A. Pereira da Silva (2003), "Conclusion: Where do we go from here?" in Bourguignon, Francois and Luis A. Pereira da Silva (editors), The Impact of Economic Policies on Poverty and Income Distribution: Evaluation Techniques and Tools, New York: World Bank and Oxford University Press.

Bourguignon, Francois, Anne-Sophie Robillard and Sherman Robinson (2002), "Representative Versus Real Households in the Macroeconomic Models of Inequality," International Food Policy Research, processed.

Broda, Christian and David Weinstein (2004), "Globalization and the Gains from Variety," National Bureau of Economic Research Working Paper No. 10314. Available at: www.nber.org/papers/w10314.

Brown, Drusilla and Robert Stern (2001), "Measurement and Modeling of the Economic Effects of Trade and Investment Barriers in Services," Review of International Economics, 9(2): 262-286.

Chen, Shaohua and Marin Ravallion (2004), "Welfare Impacts of China's Accession to the WTO," The World Bank Economic Review, 18(1), 29-57.

Ciccone, A. and R. Hall (1996), "Productivity and the Density of Economic Activity," American Economic Review, 86(1):54-70.

Cockburn, John (2001), "Trade Liberalization and Poverty in Nepal: A Computable General Equilibrium Micro Simulation Analysis," CREFA Working Paper 01-18; available at www.crefa.ecn.ulaval.ca/cahier/0118.pdf.

Cororaton, Caesar B.(2003) "Analyzing the Impact of Philippine Tariff Reform on Unemployment, Distribution and Poverty Using CGE-Microsimulation Approach." available at: http://www.ifpri.org/events/seminars/2003/20031014/cororaton_EPIAM.pdf.

Daniels, P.W. (1985), Service Industries: A Geographical Appraisal, New York: Methuen \& Co.

Dee, Philippa, Kevin Hanslow and Tien Phamduc (2003), "Measuring the Costs of Barriers to Trade in Services," in Takatoshi Ito and Anne Krueger (eds.), Trade in Services in the Asia-Pacific Region, Chicago: University of Chicago Press.

Elbers, C., Lanjouw, J.O., and P. Lanjouw (2003), "Micro-level Estimation of Poverty and Inequality," Econometrica 71 (1), January, 355-64 
Ethier, W.J. (1982), "National and International Returns to Scale in the Modern Theory of International Trade," American Economic Review, 72(2), 389-405.

Feenstra, R., D., Madani, T.H. Yang and C.Y. Liang (1999), Testing Endogenous Growth in South Korea and Taiwan, Journal of Development Economics 60, 317-341.

Feenstra, Robert C. and Hiau Looi Kee (2004), "On the Measurement of Product Variety in Trade," American Economic Review, 94(2), 145-149.

Findlay, Christopher and Tony Warren, eds. (2000), Impediments to Trade in Services: Measurement and Policy Implications, London: Routledge.

Fujita, Masahisa, Paul Krugman and Anthony J. Venables (1999), The Spatial Economy: Cities, Regions, and International Trade, Cambridge: MIT Press.

G rtz, Mette; Harrison, Glenn W.; Nielson, Claus Kastberg, and Rutherford, Thomas F. (2000), "Welfare Gains of Extended Opening Hours in Denmark," Economics Working Paper B00-03, Moore School of Business, University of South Carolina; available from http://dmsweb.moore.sc.edu/glenn/wp/.

Harrison, Glenn W, Thomas F. Rutherford and David G. Tarr. (1997), "Economic Implications for Turkey of a Customs Union With the European Union," European Economic Review, $41,861-870$.

Harrison, Glenn W, Thomas F. Rutherford and David G. Tarr (1997), "Quantifying the Uruguay Round," Economic Journal, 107 No. 444, September, 1405-1430.

Harrison, Glenn W, Thomas F. Rutherford and David G. Tarr (2003), “Trade Liberalization, Poverty and Efficient Equity," Journal of Development Economics, 71, June, 97-128.

Harrison, Glenn W, Thomas F. Rutherford, David G. Tarr and Angelo Gurgel (forthcoming), "Trade Policy and Poverty Reduction in Brazil," World Bank Economic Review.

Hummels, David (1995), "Global Income Clustering and Trade in Intermediate Goods," Graduate School of Business, University of Chicago.

Hummels, David and Peter Klenow (2002), "The Variety and Quality of a Nation's Trade," National Bureau of Economic Research Working Paper Number 8712.

Ianchovichina, Elena and Will Martin (2004), "Impacts of China's Accession to the World Trade Organization," World Bank Economic Review, 18(1), 3-27.

Ivanic, Maros (2004), "Reconciliation of the GTAP and Household Survey Data," GTAP Resource Memorandum No. 1408, Available at:

http://www.gtap.agecon.purdue.edu/resources/res_display.asp?RecordID=1408

Jensen, Jesper, and David G. Tarr (2003), “Trade, Exchange Rate and Energy Pricing Reform in Iran: Potentially Large Efficiency Effects and Gains to the Poor," Review of Development Economics, 7(4), November, 543-662. 
Jensen, Jesper, Thomas F. Rutherford and David G. Tarr (2004), "The Impact of Liberalizing Barriers to Foreign Direct Investment in Services: The Case of Russian Accession to the World Trade Organization," June. Available at www.worldbank.org/trade/russia-wto.

Markusen, James, Thomas Rutherford and David Tarr (2000), "Foreign Direct Investment in Services and the Domestic Market for Expertise," Policy and Research Working Paper No. 2143, The World Bank, Available at www.worldbank.org/trade.

Marshall, J.N. (1988), Services and Uneven Development, London: Oxford University Press.

McKee, D.L. (1988), Growth, Development, and the Service Economy in the Third World, New York: Praeger Publishers.

Melo, Jaime de and David G. Tarr (1992), A General Equilibrium Analysis of US Foreign Trade Policy, Cambridge, MA.: MIT Press.

Moriarity, C. and F. Scheuren (2003), "A Note on Rubin's Statistical Matching Using File Concatenation with Adjusted Weights and Multiple Imputations," Journal of Business and Economic Statistics, January, 65-73.

Rao, J.N.K. (1999), "Some Recent Advances in Model-Based Small Area Estimation," Survey Methodology, 25 (2), December, 175-186.

Ravallion, Martin and Michael Loshkin (2004), "Gainers and Losers from Trade Reform in Morocco,” World Bank Policy and Research Working Paper Number 3368.

Romer, Paul. (1994), "New Goods, Old Theory and the Welfare Costs of Trade Restrictions," Journal of Development Economics," 43(1), February, 5-38.

Rutherford, Thomas F. (1999a), "Applied General Equilibrium Modeling with MPSGE as a GAMS Subsystem: An Overview of the Modeling Framework and Syntax," Computational Economic, 14 (1/2), October, 1-46.

Rutherford, Thomas F. (1999b), "Sequential Joint Maximization," in John Weyant (ed.), Energy and Environmental Policy Modeling, Kluwer.

Rutherford, Thomas F. and David G. Tarr (2002), "Trade Liberalization, product variety and growth in a small open economy: a quantitative assessment," Journal of International Economics, 56 (2), March, 247-272.

Schott, Peter (forthcoming), "Across-Product versus Within-Product Specialization in International Trade," Quarterly Journal of Economics.

Tybout, James and Daniel Westbrook (1995), "Trade Liberalization and the Dimensions of Efficiency Change in Mexican Manufacturing Industries," Journal of International Economics, 39, 53-78.

Winters, L. Alan, Neil McCulloch and Andrew McKay (2004), "Trade Liberalization and Poverty: The Evidence So Far," Journal of Economic Literature 42, March, 72115. 
Table 1. Structure of Value Added in Russia: Factor shares from the Input-Output table and after reconciliation with the Household Budget Survey (HBS)

\begin{tabular}{|c|c|c|c|c|c|c|c|c|c|}
\hline & & & & Inpu & Output Tal & & $\operatorname{Reco}$ & iled with $\mathrm{H}$ & \\
\hline & & $\begin{array}{l}\text { Value } \\
\text { Added }\end{array}$ & Added (\%) & $\begin{array}{r}\text { Unskilled } \\
\text { Labor \% }\end{array}$ & $\begin{array}{r}\text { Skilled } \\
\text { Labor \% }\end{array}$ & Capital \% & $\begin{array}{r}\text { Unskilled } \\
\text { Labor \% }\end{array}$ & $\begin{array}{r}\text { Skilled } \\
\text { Labor \% }\end{array}$ & Capital \% \\
\hline & Sectors & 1354 & 100.0 & 28 & 12 & 61 & 21 & 63 & 16 \\
\hline Business Services: & Railway transportation & 45 & 3.3 & 30 & 24 & 45 & 11 & 85 & 5 \\
\hline & Truck transportation & 20 & 1.5 & 31 & 33 & 36 & 8 & 88 & 4 \\
\hline & Pipelines transportation & 49 & 3.6 & 5 & 3 & 92 & 11 & 58 & 31 \\
\hline & Maritime transportation & 4 & 0.3 & 32 & 19 & 48 & 14 & 81 & 5 \\
\hline & Air transportation & 8 & 0.6 & 48 & 29 & 24 & 14 & 84 & 2 \\
\hline & Other transportation & 14 & 1.1 & 21 & 20 & 59 & 9 & 85 & 6 \\
\hline & Telecommunications & 16 & 1.2 & 31 & 16 & 53 & 16 & 79 & 5 \\
\hline & Financial services & 21 & 1.5 & 33 & 27 & 40 & 10 & 86 & 4 \\
\hline & Science \& science servicing & 11 & 0.8 & 56 & 10 & 34 & 35 & 61 & 4 \\
\hline & Subtotal: & 188 & 13.9 & 2583 & 1794 & 5623 & 1244 & 7626 & 1130 \\
\hline Differentiated Goods: & Ferrous metallurgy & 26 & 1.9 & 18 & 17 & 65 & 9 & 85 & 7 \\
\hline & Non-ferrous metallurgy & 31 & 2.3 & 18 & 13 & 69 & 12 & 81 & 7 \\
\hline & Chemical \& oil-chemical industry & 24 & 1.8 & 28 & 10 & 61 & 20 & 74 & 7 \\
\hline & Mechanical engineering \& metal-working & 71 & 5.2 & 48 & 11 & 41 & 30 & 66 & 4 \\
\hline & Timber $\&$ woodworking $\&$ pulp $\&$ paper industry & 19 & 1.4 & 37 & 17 & 45 & 17 & 79 & 5 \\
\hline & Construction materials industry & 21 & 1.6 & 33 & 13 & 54 & 19 & 75 & 5 \\
\hline & Light industry & 9 & 0.7 & 66 & 3 & 30 & 63 & 32 & 5 \\
\hline & Food industry & 45 & 3.3 & 25 & 11 & 64 & 17 & 76 & 7 \\
\hline & Other industries & 9 & 0.6 & 54 & 19 & 28 & 22 & 76 & 3 \\
\hline & Subtotal: & 255 & 18.8 & 3436 & 1226 & 5338 & 2125 & 7312 & 562 \\
\hline Extractive Industries: & Oil extraction & 39 & 2.9 & 4 & 9 & 87 & 1 & 12 & 87 \\
\hline & Gas & 12 & 0.9 & 4 & 7 & 89 & 1 & 10 & 89 \\
\hline & Coalmining & 15 & 1.1 & 13 & 41 & 47 & 2 & 52 & 47 \\
\hline & Subtotal: & 67 & 4.9 & 581 & 1580 & 7840 & 76 & 2084 & 7840 \\
\hline Constant Returns & Electric industry & 48 & 3.6 & 19 & 17 & 64 & 9 & 84 & 6 \\
\hline Industries: & Oil processing & 10 & 0.8 & 7 & 17 & 77 & 3 & 89 & 8 \\
\hline & Other fuel industries & 0 & 0.0 & 30 & 2 & 68 & 49 & 33 & 18 \\
\hline & Construction & 116 & 8.6 & 30 & 26 & 44 & 10 & 86 & 4 \\
\hline & Agriculture \& forestry & 103 & 7.6 & 25 & 2 & 73 & 47 & 31 & 22 \\
\hline & Post & 4 & 0.3 & 23 & 11 & 66 & 15 & 78 & 7 \\
\hline & Trade & 309 & 22.9 & 10 & 3 & 87 & 20 & 53 & 27 \\
\hline & Public catering & 2 & 0.1 & 67 & 28 & 5 & 19 & 81 & 1 \\
\hline & Other goods-producing sectors & 11 & 0.8 & 72 & 23 & 5 & 23 & 76 & 1 \\
\hline & Communal \& consumer services & 76 & 5.6 & 24 & 9 & 67 & 19 & 72 & 9 \\
\hline & Public health \& sports \& social security & 42 & 3.1 & 59 & 7 & 34 & 44 & 52 & 4 \\
\hline & Education \& culture \& art & 54 & 4.0 & 68 & 5 & 28 & 56 & 40 & 4 \\
\hline & Geology \& hydrometeorology & 3 & 0.2 & 63 & 7 & 30 & 45 & 52 & 3 \\
\hline & Administration \& public associations & 65 & 4.8 & 66 & 22 & 12 & 22 & 76 & 1 \\
\hline & Subtotal: & 844 & 62.3 & 2806 & 957 & 6237 & 2486 & 5999 & 1515 \\
\hline
\end{tabular}


Table 2. Tariff Rates, Export Tax Rates, Estimated Ad Valorem Equivalence of Barriers to FDI in Services Sectors and Estimated Improved Market Access *

(ad-valorem in \%) -- by sector

\begin{tabular}{|c|c|c|c|c|c|c|}
\hline \multirow{2}{*}{\multicolumn{2}{|c|}{ Sectors }} & \multirow[b]{2}{*}{ Tariff rates } & \multirow{2}{*}{$\begin{array}{l}\text { Export tax } \\
\text { rates }\end{array}$} & \multirow{2}{*}{$\begin{array}{l}\text { Estimated } \\
\text { change in } \\
\text { world market } \\
\text { nrice }\end{array}$} & \multicolumn{2}{|c|}{ Equivalent $\%$ barriers to FDI } \\
\hline & & & & & & Post-WTO \\
\hline ELE & Electric industry & 4.5 & 0 & 0 & & \\
\hline OLE & Oil extraction & 0 & 7.9 & 0 & & \\
\hline OLP & Oil processing & 3.8 & 4.6 & 0 & & \\
\hline GAS & Gas & 0.5 & 18.8 & 0 & & \\
\hline $\mathrm{COA}$ & Coalmining & 0 & 0 & 0 & & \\
\hline OFU & Other fuel industries & 2.6 & 2.6 & 0 & & \\
\hline FME & Ferrous metallurgy & 2.9 & 0.4 & 1.5 & & \\
\hline NFM & Non-ferrous metallurgy & 7.4 & 5.3 & 1.5 & & \\
\hline CHM & Chemical \& oil-chemical industry & 7.1 & 1.6 & 1.5 & & \\
\hline MWO & Mechanical engineering \& metal-working & 7.2 & 0 & 0 & & \\
\hline ТРP & Timber \& woodworking \& pulp \& paper industry & 9.9 & 6.9 & 0 & & \\
\hline CNM & Construction materials industry & 10.6 & 1.6 & 0 & & \\
\hline CLO & Light industry & 11.8 & 4.1 & 0.5 & & \\
\hline FOO & Food industry & 11.3 & 3.1 & 0.5 & & \\
\hline OTH & Other industries & 6.4 & 0 & 0.5 & & \\
\hline AGF & Agriculture \& forestry & 8.2 & 0.6 & 0 & & \\
\hline OIN & Other goods-producing sectors & 0 & 0 & 0.5 & & \\
\hline TMS & Telecommunications & & & & 33 & 0 \\
\hline SCS & Science \& science servicing & & & & 33 & 0 \\
\hline FIN & Financial services & & & & 36 & 0 \\
\hline RLW & Railway transportation & & & & 33 & 0 \\
\hline TRK & Truck transportation & & & & 33 & 0 \\
\hline PIP & Pipelines transportation & & & & 33 & 0 \\
\hline MAR & Maritime transportation & & & & 95 & 80 \\
\hline AIR & Air transportation & & & & 90 & 75 \\
\hline TRO & Other transportation & & & & 33 & 0 \\
\hline
\end{tabular}

* Source: Authors' estimates 
Table 3. Factor Income Shares by Consumption Decile

\begin{tabular}{|c|c|c|c|c|c|c|c|c|c|}
\hline & \multicolumn{3}{|c|}{ All Households } & \multicolumn{3}{|c|}{ Rural Households } & \multicolumn{3}{|c|}{ Urban Households } \\
\hline & $\begin{array}{r}\text { Unskilled } \\
\text { Labor \% } \\
\end{array}$ & $\begin{array}{r}\text { Skilled } \\
\text { Labor \% } \\
\end{array}$ & Capital \% & $\begin{array}{r}\text { Unskilled } \\
\text { Labor \% } \\
\end{array}$ & $\begin{array}{r}\text { Skilled } \\
\text { Labor \% } \\
\end{array}$ & Capital \% & $\begin{array}{r}\text { Unskilled } \\
\text { Labor \% } \\
\end{array}$ & $\begin{array}{r}\text { Skilled } \\
\text { Labor \% } \\
\end{array}$ & Capital \% \\
\hline Decile $1(0-10 \%)$ & 40.9 & 56.8 & 2.3 & 45.8 & 50.8 & 3.4 & 35.6 & 63.2 & 1.2 \\
\hline Decile $2(11-20 \%)$ & 37.6 & 58.5 & 3.9 & 42.8 & 51.5 & 5.8 & 34.1 & 63.4 & 2.6 \\
\hline Decile $3(21-30 \%)$ & 32.2 & 62.3 & 5.4 & 40.0 & 52.5 & 7.5 & 28.5 & 67.0 & 4.5 \\
\hline Decile $4(31-40 \%)$ & 30.1 & 62.9 & 7.0 & 36.8 & 54.2 & 9.1 & 27.3 & 66.5 & 6.2 \\
\hline Decile $5(41-50 \%)$ & 27.5 & 62.5 & 10.0 & 34.7 & 53.7 & 11.6 & 25.0 & 65.5 & 9.5 \\
\hline Decile $6(51-60 \%)$ & 25.3 & 60.9 & 13.8 & 35.4 & 49.3 & 15.3 & 22.1 & 64.5 & 13.3 \\
\hline Decile 7 (61-70\%) & 20.7 & 61.4 & 17.9 & 33.2 & 50.4 & 16.4 & 17.6 & 64.1 & 18.3 \\
\hline Decile $8(71-80 \%)$ & 16.8 & 62.1 & 21.1 & 31.2 & 48.0 & 20.8 & 13.9 & 65.0 & 21.1 \\
\hline Decile $9(81-90 \%)$ & 16.1 & 55.2 & 28.7 & 28.0 & 46.6 & 25.4 & 14.4 & 56.5 & 29.2 \\
\hline Decile $10(91-100 \%)$ & 11.2 & 47.2 & 41.7 & 23.3 & 39.9 & 36.8 & 10.5 & 47.6 & 41.9 \\
\hline
\end{tabular}


Table 4. Shares of Consumption Expenditure on Goods and Services, by Decile (Rural versus Total)

\begin{tabular}{|c|c|c|c|c|c|c|c|}
\hline \multirow{2}{*}{\multicolumn{2}{|c|}{ Sectors }} & \multicolumn{2}{|c|}{ Decile $1(0-10 \%)^{a /}$} & \multicolumn{2}{|c|}{ Decile $5(41-50 \%)$} & \multicolumn{2}{|c|}{ Decile $10(91-100 \%){ }^{b /}$} \\
\hline & & Urban & Rural & Urban & Rural & Urban & Rural \\
\hline ELE & Electric industry & 0.9 & 0.7 & 0.6 & 0.4 & 0.3 & 0.3 \\
\hline OLE & Oil extraction & 0.0 & 0.0 & 0.0 & 0.0 & 0.0 & 0.0 \\
\hline OLP & Oil processing & 0.5 & 0.4 & 0.8 & 0.8 & 1.7 & 1.3 \\
\hline GAS & Gas & 0.7 & 1.2 & 0.3 & 0.6 & 0.1 & 0.2 \\
\hline $\mathrm{COA}$ & Coalmining & 0.2 & 0.9 & 0.1 & 1.0 & 0.0 & 0.2 \\
\hline OFU & Other fuel industries & 0.0 & 0.0 & 0.0 & 0.0 & 0.0 & 0.0 \\
\hline FME & Ferrous metallurgy & 0.0 & 0.0 & 0.0 & 0.0 & 0.0 & 0.0 \\
\hline NFM & Non-ferrous metallurgy & 0.0 & 0.0 & 0.0 & 0.0 & 0.0 & 0.0 \\
\hline CHM & Chemical \& oil-chemical industry & 3.9 & 2.7 & 2.8 & 1.7 & 1.5 & 1.2 \\
\hline MWO & Mechanical engineering \& metal-working & 1.3 & 1.3 & 3.0 & 3.9 & 15.2 & 16.9 \\
\hline TPP & Timber \& woodworking \& pulp \& paper industry & 1.1 & 0.7 & 1.3 & 0.9 & 3.1 & 2.0 \\
\hline CNM & Construction materials industry & 0.3 & 0.4 & 0.4 & 0.5 & 1.0 & 1.2 \\
\hline CLO & Light industry & 15.2 & 12.7 & 15.7 & 12.1 & 16.8 & 11.4 \\
\hline FOO & Food industry & 48.7 & 29.9 & 43.6 & 24.6 & 27.1 & 18.6 \\
\hline OTH & Other industries & 0.4 & 0.2 & 0.5 & 0.3 & 0.9 & 0.4 \\
\hline $\mathrm{CON}$ & Construction & 0.0 & 0.0 & 0.0 & 0.0 & 1.8 & 1.1 \\
\hline AGF & Agriculture \& forestry & 9.5 & 38.3 & 10.8 & 42.2 & 7.5 & 30.3 \\
\hline RLW & Railway transportation & 0.4 & 0.2 & 0.7 & 0.3 & 0.7 & 0.4 \\
\hline TRK & Truck transportation & 0.6 & 2.2 & 0.7 & 1.6 & 1.1 & 3.0 \\
\hline PIP & Pipelines transportation & 0.0 & 0.0 & 0.0 & 0.0 & 0.0 & 0.0 \\
\hline MAR & Maritime transportation & 0.1 & 0.0 & 0.0 & 0.0 & 0.0 & 0.0 \\
\hline AIR & Air transportation & 0.1 & 0.0 & 0.8 & 0.2 & 4.6 & 2.0 \\
\hline TRO & Other transportation & 1.5 & 0.5 & 1.4 & 0.4 & 0.8 & 0.3 \\
\hline TMS & Telecommunications & 1.2 & 0.6 & 1.5 & 0.6 & 1.2 & 0.7 \\
\hline PST & Post & 0.3 & 0.1 & 0.4 & 0.2 & 0.2 & 0.3 \\
\hline TRD & Trade & 0.0 & 0.0 & 0.0 & 0.0 & 0.0 & 0.0 \\
\hline CAT & Public catering & 0.8 & 0.8 & 1.7 & 0.8 & 2.4 & 1.4 \\
\hline OIN & Other goods-producing sectors & 0.3 & 0.3 & 0.6 & 0.3 & 0.9 & 0.5 \\
\hline PSM & Communal \& consumer services & 8.5 & 2.0 & 8.0 & 2.5 & 5.0 & 2.2 \\
\hline SSM & Public health \& sports \& social security & 1.3 & 0.7 & 1.3 & 0.7 & 2.6 & 0.7 \\
\hline ECM & Education \& culture \& art & 0.7 & 0.3 & 0.9 & 0.7 & 1.3 & 1.2 \\
\hline SCS & Science \& science servicing & 0.0 & 0.0 & 0.0 & 0.0 & 0.0 & 0.0 \\
\hline GEO & Geology \& hydrometeorology & 0.0 & 0.0 & 0.0 & 0.0 & 0.0 & 0.0 \\
\hline FIN & Financial services & 1.0 & 0.5 & 0.8 & 0.6 & 1.2 & 0.7 \\
\hline
\end{tabular}

\footnotetext{
${ }^{\mathrm{a} /}$ Poorest ten percent of the population.

${ }^{b /}$ Richest ten percent of the population.
} 
Table 5: Impact of WTO Accession in 55,000 Household Model on Economy-Wide Variables in Russia -- Policy Results and Decomposition of Effects

(results are percentage change from initial equilibrium)

\begin{tabular}{|c|c|c|c|c|c|c|c|c|}
\hline & \multirow[t]{2}{*}{ Benchmark } & $\begin{array}{l}\text { WTO } \\
\text { accession }\end{array}$ & $\begin{array}{l}\text { WTO accession } \\
\text { (equal Ruble } \\
\text { transfers) }\end{array}$ & $\begin{array}{c}\text { Improved } \\
\text { market access } \\
\text { only }\end{array}$ & $\begin{array}{l}\text { Tariff reform } \\
\text { only }\end{array}$ & $\begin{array}{c}\text { Reform of FDI } \\
\text { barriers only }\end{array}$ & CRTS Model & $\begin{array}{l}\text { WTO Accession } \\
\text { with partial } \\
\text { reform of FDI } \\
\text { barriers }\end{array}$ \\
\hline & & (1) & (2) & (3) & $(4)$ & (5) & $(6)$ & $(7)$ \\
\hline \multicolumn{9}{|l|}{ Aggregate welfare } \\
\hline Welfare (EV as $\%$ of consumption) & & 7.3 & 7.2 & 0.7 & 1.3 & 5.3 & 1.2 & 4.1 \\
\hline Welfare (EV as \% of GDP) & & 3.4 & 3.4 & 0.3 & 0.6 & 2.4 & 0.6 & 1.9 \\
\hline \multicolumn{9}{|l|}{ Government budget } \\
\hline Tariff revenue (\% of GDP) & 1.4 & 0.9 & 0.9 & 1.4 & 0.8 & 1.4 & 0.9 & 0.8 \\
\hline Tariff revenue ( $\%$ change) & & -33.2 & -33.2 & 8.7 & -38.3 & 10.9 & -43.5 & -35.2 \\
\hline \multicolumn{9}{|l|}{ Aggregate trade } \\
\hline Real exchange rate (\% change) & & 2.6 & 2.6 & -0.5 & 2.0 & 1.1 & 0.3 & 1.8 \\
\hline Aggregate exports (\% change) & & 14.4 & 14.4 & 2.3 & 8.1 & 3.7 & 5.9 & 11.9 \\
\hline \multicolumn{9}{|l|}{ Returns to mobile factors } \\
\hline Unskilled Labor ( $\%$ change) & & 3.7 & 3.7 & 0.1 & 0.6 & 2.9 & 1.0 & 1.7 \\
\hline Skilled Labor (\% change) & & 5.3 & 5.3 & 0.7 & 1.7 & 2.8 & 1.9 & 3.2 \\
\hline Capital (\% change) & & 1.8 & 1.8 & -0.6 & 1.0 & 1.4 & 0.9 & 2.2 \\
\hline \multicolumn{9}{|l|}{ Percent of Factors that must adjust } \\
\hline Unskilled labor & & 1.2 & 1.2 & 0.3 & 1.2 & 0.4 & 0.8 & 1.3 \\
\hline Skilled labor & & 1.4 & 1.4 & 0.5 & 0.6 & 0.7 & 0.6 & 1.0 \\
\hline Capital & & 0.5 & 0.5 & 0.1 & 0.3 & 0.1 & 0.3 & 0.4 \\
\hline
\end{tabular}

* Source: Authors' estimates 
Table 6: Impact of WTO Accession on Russian industry and labor by sector (percentage change in variable -- full versus partial FDI reform)

\begin{tabular}{|c|c|c|c|c|c|c|c|c|c|c|}
\hline \multirow[b]{3}{*}{ Sectors $^{\mathrm{a} /}$} & \multicolumn{5}{|c|}{ WTO Accession } & \multicolumn{5}{|c|}{ WTO Accession with Partial Reform of FDI Barriers } \\
\hline & output & exports & imports & $\begin{array}{c}\text { skilled } \\
\text { employment }\end{array}$ & $\begin{array}{c}\text { unskilled } \\
\text { employment }\end{array}$ & output & exports & imports & $\begin{array}{c}\text { skilled } \\
\text { employment }\end{array}$ & $\begin{array}{c}\text { unskilled } \\
\text { employment }\end{array}$ \\
\hline & \multicolumn{5}{|c|}{$(1)$} & \multicolumn{5}{|c|}{$(2)$} \\
\hline ELE & 2 & -1 & 8 & 1 & 3 & 1 & -1 & 6 & 0 & 2 \\
\hline OLE & 3 & 3 & 3 & 0 & 2 & 1 & 1 & -1 & -1 & 0 \\
\hline OLP & 2 & 5 & 7 & 1 & 3 & -1 & -1 & 6 & -1 & 1 \\
\hline GAS & 4 & 10 & 43 & 19 & 20 & -1 & -5 & -4 & -5 & -4 \\
\hline $\mathrm{COA}$ & 5 & 11 & 9 & 5 & 7 & 2 & -1 & 7 & 3 & 4 \\
\hline OFU & 1 & 31 & 4 & 0 & 2 & -1 & 5 & 1 & -1 & 0 \\
\hline FME & 14 & 32 & 7 & 13 & 15 & 10 & 25 & 6 & 10 & 11 \\
\hline NFM & 29 & 42 & 36 & 28 & 30 & 40 & 55 & 39 & 39 & 41 \\
\hline CHM & 9 & 27 & 9 & 7 & 9 & 6 & 22 & 8 & 6 & 7 \\
\hline MWO & -14 & -12 & 22 & -15 & -14 & -14 & -12 & 21 & -15 & -13 \\
\hline ТPP & -5 & 3 & 35 & -6 & -5 & -8 & -3 & 34 & -9 & -7 \\
\hline CNM & -6 & -1 & 74 & -8 & -6 & -7 & -5 & 72 & -7 & -6 \\
\hline CLO & -9 & 1 & 8 & -11 & -10 & -9 & 1 & 6 & -10 & -9 \\
\hline FOO & -13 & -7 & 38 & -15 & -14 & -13 & -7 & 33 & -14 & -13 \\
\hline $\mathrm{OTH}$ & -6 & 0 & 47 & -8 & -6 & -7 & -2 & 46 & -7 & -6 \\
\hline $\mathrm{CON}$ & 0 & 1 & 0 & -1 & 0 & 0 & 0 & 0 & 0 & 1 \\
\hline AGF & -2 & -4 & 11 & -3 & -2 & -3 & -3 & 8 & -4 & -3 \\
\hline RLW & 0 & -4 & 224 & 0 & 1 & 0 & -2 & 51 & 0 & 1 \\
\hline TRK & 8 & 7 & 42 & 7 & 8 & 1 & 1 & 12 & 1 & 3 \\
\hline PIP & -4 & 0 & 149 & -5 & -3 & -3 & 0 & 33 & -3 & -2 \\
\hline MAR & 2 & 7 & -4 & -2 & 0 & 0 & 2 & -1 & -1 & 1 \\
\hline AIR & -2 & 0 & 24 & -6 & -4 & -2 & -1 & 11 & -3 & -1 \\
\hline TRO & 4 & 2 & 105 & 2 & 4 & 0 & -1 & 26 & 0 & 1 \\
\hline TMS & 7 & 10 & 48 & 6 & 7 & -2 & -2 & 17 & -2 & -1 \\
\hline PST & 3 & 5 & 2 & 0 & 1 & 1 & 0 & 2 & 0 & 1 \\
\hline TRD & 6 & 2 & 9 & 4 & 6 & 4 & 1 & 6 & 3 & 5 \\
\hline CAT & 6 & 16 & 0 & 2 & 4 & 4 & 12 & -1 & 2 & 4 \\
\hline OIN & -2 & 2 & 30 & -3 & -2 & -3 & 0 & 27 & -4 & -2 \\
\hline PSM & 2 & -2 & 5 & 1 & 3 & 1 & -1 & 2 & 1 & 2 \\
\hline SSM & 1 & 1 & 1 & -1 & 0 & 0 & 2 & 0 & -1 & 1 \\
\hline ECM & 0 & -2 & 2 & -1 & 0 & 0 & 0 & 0 & -1 & 1 \\
\hline SCS & -11 & -2 & 149 & -13 & -12 & -6 & -3 & 52 & -7 & -6 \\
\hline GEO & 0 & 0 & 0 & -3 & -1 & 0 & 0 & 0 & -1 & 0 \\
\hline FIN & 8 & 16 & 54 & 6 & 7 & -1 & 0 & 18 & -2 & 0 \\
\hline ADM & 0 & 0 & 0 & -8 & -6 & 0 & 0 & 0 & -2 & -1 \\
\hline
\end{tabular}

\footnotetext{
a/ Sector codes are defined in Table 4 .
} 
Table 7. The Mean Welfare Impact of WTO Accession on Russian Households, from Poorest

to Richest (welfare change as a percent of consumption)

\begin{tabular}{|c|c|c|c|c|c|c|c|}
\hline \multicolumn{2}{|l|}{ Household types ${ }^{\text {a/ }}$} & \multirow{2}{*}{$\begin{array}{c}\begin{array}{c}\text { WTO } \\
\text { accession }\end{array} \\
(1) \\
\end{array}$} & \multirow{2}{*}{$\begin{array}{c}\text { WTO accession } \\
\text { (equal Ruble } \\
\text { transfers) a/ }\end{array}$} & \multirow{2}{*}{$\begin{array}{c}\begin{array}{c}\text { Improved } \\
\text { market access } \\
\text { only }\end{array} \\
(3) \\
\end{array}$} & \multirow{2}{*}{\begin{tabular}{|c|}
$\begin{array}{c}\text { Tariff reform } \\
\text { only }\end{array}$ \\
$(4)$ \\
\end{tabular}} & \multirow{2}{*}{$\begin{array}{c}\begin{array}{c}\text { Reform of } \\
\text { FDI barriers } \\
\text { only }\end{array} \\
(5) \\
\end{array}$} & \multirow{2}{*}{$\begin{array}{c}\text { CRTS Model } \\
(6) \\
\end{array}$} \\
\hline & & & & & & & \\
\hline \multirow[t]{3}{*}{ Decile $1(0-10 \%)$} & Rural & 7.0 & 8.3 & 0.9 & 0.8 & 5.3 & 1.0 \\
\hline & Urban & 8.3 & 9.3 & 1.1 & 1.4 & 5.8 & 1.4 \\
\hline & Combined & 7.6 & 8.8 & 1.0 & 1.1 & 5.5 & 1.2 \\
\hline \multirow[t]{3}{*}{ Decile $2(11-20 \%)$} & Rural & 6.7 & 7.3 & 0.8 & 0.8 & 5.1 & 0.9 \\
\hline & Urban & 8.2 & 8.8 & 1.1 & 1.4 & 5.6 & 1.4 \\
\hline & Combined & 7.6 & 8.2 & 1.0 & 1.1 & 5.4 & 1.2 \\
\hline \multirow[t]{3}{*}{ Decile $3(21-30 \%)$} & Rural & 6.6 & 7.1 & 0.8 & 0.8 & 5.0 & 0.9 \\
\hline & Urban & 8.3 & 8.7 & 1.1 & 1.4 & 5.6 & 1.4 \\
\hline & Combined & 7.7 & 8.1 & 1.0 & 1.2 & 5.4 & 1.3 \\
\hline \multirow{3}{*}{ Decile $4(31-40 \%)$} & Rural & 6.6 & 6.9 & 0.8 & 0.8 & 5.0 & 0.9 \\
\hline & Urban & 8.2 & 8.4 & 1.0 & 1.4 & 5.6 & 1.4 \\
\hline & Combined & 7.7 & 8.0 & 1.0 & 1.3 & 5.4 & 1.3 \\
\hline \multirow[t]{3}{*}{ Decile $5(41-50 \%)$} & Rural & 6.4 & 6.6 & 0.7 & 0.8 & 4.8 & 0.9 \\
\hline & Urban & 8.1 & 8.3 & 1.0 & 1.4 & 5.6 & 1.4 \\
\hline & Combined & 7.7 & 7.8 & 0.9 & 1.3 & 5.4 & 1.3 \\
\hline \multirow[t]{3}{*}{ Decile $6(51-60 \%)$} & Rural & 6.2 & 6.2 & 0.7 & 0.8 & 4.7 & 0.8 \\
\hline & Urban & 8.0 & 8.0 & 0.9 & 1.5 & 5.5 & 1.4 \\
\hline & Combined & 7.5 & 7.6 & 0.9 & 1.3 & 5.3 & 1.3 \\
\hline \multirow[t]{3}{*}{ Decile $7(61-70 \%)$} & Rural & 6.2 & 6.2 & 0.6 & 0.8 & 4.8 & 0.8 \\
\hline & Urban & 7.8 & 7.8 & 0.8 & 1.5 & 5.5 & 1.4 \\
\hline & Combined & 7.5 & 7.5 & 0.8 & 1.3 & 5.3 & 1.3 \\
\hline \multirow[t]{3}{*}{ Decile $8(71-80 \%)$} & Rural & 6.0 & 5.9 & 0.6 & 0.8 & 4.6 & 0.8 \\
\hline & Urban & 7.8 & 7.8 & 0.8 & 1.5 & 5.4 & 1.4 \\
\hline & Combined & 7.5 & 7.4 & 0.8 & 1.4 & 5.3 & 1.3 \\
\hline \multirow[t]{3}{*}{ Decile $9(81-90 \%)$} & Rural & 6.1 & 5.9 & 0.5 & 0.8 & 4.8 & 0.8 \\
\hline & Urban & 7.3 & 7.2 & 0.6 & 1.4 & 5.3 & 1.2 \\
\hline & Combined & 7.2 & 7.0 & 0.6 & 1.3 & 5.2 & 1.2 \\
\hline \multirow[t]{3}{*}{ Decile 10 (91-100\%) } & Rural & 5.6 & 5.3 & 0.3 & 0.8 & 4.4 & 0.7 \\
\hline & Urban & 6.8 & 6.5 & 0.3 & 1.3 & 5.2 & 1.1 \\
\hline & Combined & 6.8 & 6.4 & 0.3 & 1.3 & 5.1 & 1.1 \\
\hline
\end{tabular}

a/ The model is executed with 55 thousand households. Decile 1 is the poorest ten percent of all households on a per capita income basis. Results for decile 1 (combined, rural and urban) are a weighted average of the equivalent variation as a percentage of consumption of the households (combined, rural and urban) in the decile. Other deciles are calculated analogously.

Source: Authors' estimates 
Table 8. Regressions of the gains from the WTO accession on the household characteristics

\begin{tabular}{|c|c|c|c|c|c|c|}
\hline & Whole & & Ву pe & ita inc & intile & \\
\hline & sample & 1 & 2 & 3 & 4 & 5 \\
\hline $\begin{array}{l}\text { Head of the household: } \\
\text { age of the head of the household } \\
\text { female head of the household }\end{array}$ & $\begin{array}{c}\mathbf{- 0 . 0 0 7 3} \\
{[6.83]^{* *}} \\
\mathbf{0 . 1 0} \\
{[2.93]^{* *}}\end{array}$ & $\begin{array}{r}\mathbf{- 0 . 0 0 4 0} \\
{[2.64]^{* *}} \\
\mathbf{0 . 0 0} \\
{[0.02]} \\
\end{array}$ & $\begin{array}{r}\mathbf{- 0 . 0 0 8 6} \\
{[6.26]^{* *}} \\
\mathbf{0 . 1 4} \\
{[3.62]^{* *}} \\
\end{array}$ & $\begin{array}{r}\mathbf{- 0 . 0 0 9 4} \\
{[6.65]^{* *}} \\
\mathbf{0 . 1 0} \\
{[2.27]^{*}} \\
\end{array}$ & $\begin{array}{r}\mathbf{- 0 . 0 0 8 3} \\
{[4.38]^{* *}} \\
\mathbf{0 . 2 1} \\
{[3.30]^{* *}} \\
\end{array}$ & $\begin{array}{r}\mathbf{- 0 . 0 0 3 2} \\
{[1.17]} \\
\mathbf{0 . 0 3} \\
{[0.29]} \\
\end{array}$ \\
\hline $\begin{array}{l}\text { Household characteristics: } \\
\text { household income, } \\
\text { (roubles per quarter) } \\
\text { family size } \\
\text { capital labor share is the baseline }\end{array}$ & $\begin{array}{c}\mathbf{1 . 8 4 E - 0 5} \\
{[2.34]^{*}} \\
\mathbf{0 . 0 0} \\
{[0.26]}\end{array}$ & $\begin{array}{r}-\mathbf{4 . 3 0 E - 0 5} \\
{[1.75]} \\
\mathbf{0 . 0 7} \\
{[2.73] * *}\end{array}$ & $\begin{array}{r}\mathbf{1 . 2 5 E - 0 5} \\
{[0.69]} \\
\mathbf{- 0 . 0 4} \\
{[1.10]}\end{array}$ & $\begin{array}{r}\mathbf{- 7 . 9 8 E - 0 6} \\
{[0.55]} \\
\mathbf{0 . 0 4} \\
{[0.71]}\end{array}$ & $\begin{array}{r}\mathbf{1 . 8 0 E - 0 5} \\
{[1.47]} \\
\mathbf{- 0 . 0 1} \\
{[0.16]}\end{array}$ & $\begin{array}{r}\mathbf{3 . 1 9 E - 0 5} \\
{[4.39]^{* *}} \\
\mathbf{- 0 . 0 9} \\
{[1.84]}\end{array}$ \\
\hline $\begin{array}{l}\text { skilled labor share } \\
\text { unskilled labor share }\end{array}$ & $\begin{array}{c}\mathbf{6 . 1 9} \\
{[54.51]^{* *}} \\
\mathbf{3 . 1 9} \\
{[30.64]^{* *}} \\
\end{array}$ & $\begin{array}{r}\mathbf{5 . 6 0} \\
{[12.67]^{* *}} \\
\mathbf{2 . 5 6} \\
{[6.21]^{* *}} \\
\end{array}$ & $\begin{array}{r}\mathbf{6 . 3 7} \\
{[38.92]^{* *}} \\
\mathbf{3 . 4 0} \\
{[19.08]^{* *}} \\
\end{array}$ & $\begin{array}{r}\mathbf{6 . 0 6} \\
{[44.33]^{* *}} \\
\mathbf{3 . 1 2} \\
{[23.23]^{* *}} \\
\end{array}$ & $\begin{array}{r}\mathbf{6 . 1 5} \\
{[32.70]^{* *}} \\
\mathbf{3 . 1 2} \\
{[16.63]^{* *}} \\
\end{array}$ & $\begin{array}{r}\mathbf{6 . 1 7} \\
{[27.01]^{* *}} \\
\mathbf{2 . 8 0} \\
{[12.94]^{* *}} \\
\end{array}$ \\
\hline $\begin{array}{l}\text { Locality characteristics: } \\
\text { rural }\end{array}$ & $\begin{array}{c}\mathbf{- 0 . 8 9} \\
{[10.84]^{* *}}\end{array}$ & $\begin{array}{r}\mathbf{- 0 . 7 6} \\
{[9.78] * *}\end{array}$ & $\begin{array}{r}\mathbf{- 0 . 9 4} \\
{[12.13]^{* *}}\end{array}$ & $\begin{array}{r}\mathbf{- 1 . 0 2} \\
{[10.99]^{* *}}\end{array}$ & $\begin{array}{r}\mathbf{- 0 . 9 4} \\
{[7.61]^{* *}}\end{array}$ & $\begin{array}{r}\mathbf{- 0 . 6 2} \\
{[3.13]^{* *}}\end{array}$ \\
\hline $\begin{array}{l}\text { Regional dummies: } \\
\text { Moscow and St. Petersburg } \\
\text { is the baseline }\end{array}$ & & & & & & \\
\hline Northern and North-Western & $\begin{array}{c}\mathbf{- 0 . 2 4} \\
{[1.39]}\end{array}$ & $\begin{array}{r}\mathbf{- 0 . 0 7} \\
{[0.43]}\end{array}$ & $\begin{array}{r}\mathbf{- 0 . 3 8} \\
{[2.82]^{* *}}\end{array}$ & $\begin{array}{r}\mathbf{- 0 . 3 3} \\
{[2.82]^{* *}}\end{array}$ & $\begin{array}{r}\mathbf{- 0 . 2 6} \\
{[1.15]}\end{array}$ & $\begin{array}{r}\mathbf{0 . 0 3} \\
{[0.09]}\end{array}$ \\
\hline Central and Central Black-Earth & $\begin{array}{c}\mathbf{- 0 . 7 2} \\
{[5.73]^{* *}}\end{array}$ & $\begin{array}{r}\mathbf{- 0 . 5 0} \\
{[5.42]^{* *}}\end{array}$ & $\begin{array}{r}\mathbf{- 0 . 8 2} \\
{[9.00]^{* *}}\end{array}$ & $\begin{array}{r}\mathbf{- 0 . 8 7} \\
{[11.29]^{* *}}\end{array}$ & $\begin{array}{r}\mathbf{- 0 . 7 2} \\
{[4.40]^{* *}}\end{array}$ & $\begin{array}{r}\mathbf{- 0 . 6 1} \\
{[2.20]^{*}}\end{array}$ \\
\hline Volgo-Vyatsky and Volga Basin & $\begin{array}{c}\mathbf{- 0 . 5 3} \\
{[4.00]^{* *}}\end{array}$ & $\begin{array}{r}\mathbf{- 0 . 2 8} \\
{[2.19] *}\end{array}$ & $\begin{array}{r}\mathbf{- 0 . 6 2} \\
{[6.62]^{* *}}\end{array}$ & $\begin{array}{r}\mathbf{- 0 . 6 8} \\
{[7.05]^{* *}}\end{array}$ & $\begin{array}{r}\mathbf{- 0 . 6 3} \\
{[3.99] * *}\end{array}$ & $\begin{array}{r}\mathbf{- 0 . 6 4} \\
{[2.92]^{* *}}\end{array}$ \\
\hline North Caucasian & $\begin{array}{c}\mathbf{- 0 . 7 2} \\
{[4.89]^{* *}}\end{array}$ & $\begin{array}{r}\mathbf{- 0 . 5 9} \\
{[5.10]^{* *}}\end{array}$ & $\begin{array}{r}\mathbf{- 0 . 7 6} \\
{[5.55]^{* *}}\end{array}$ & $\begin{array}{r}\mathbf{- 0 . 8 8} \\
{[6.93]^{* *}}\end{array}$ & $\begin{array}{r}\mathbf{- 0 . 8 3} \\
{[5.32]^{* *}}\end{array}$ & $\begin{array}{r}\mathbf{- 0 . 8 2} \\
{[3.21]^{* *}}\end{array}$ \\
\hline Ural & $\begin{array}{c}\mathbf{- 0 . 5 7} \\
{[4.16]^{* *}}\end{array}$ & $\begin{array}{r}\mathbf{- 0 . 3 5} \\
{[2.30]^{*}}\end{array}$ & $\begin{array}{r}\mathbf{- 0 . 6 5} \\
{[6.66]^{* *}}\end{array}$ & $\begin{array}{r}\mathbf{- 0 . 6 5} \\
{[6.27]^{* *}}\end{array}$ & $\begin{array}{r}\mathbf{- 0 . 6 4} \\
{[4.07]^{* *}}\end{array}$ & $\begin{array}{r}\mathbf{- 0 . 6 2} \\
{[2.77]^{* *}}\end{array}$ \\
\hline Western Siberian & $\begin{array}{c}\mathbf{- 0 . 4 5} \\
{[2.55]^{*}}\end{array}$ & $\begin{array}{r}\mathbf{- 0 . 4 6} \\
{[6.40]^{* *}}\end{array}$ & $\begin{array}{r}\mathbf{- 0 . 6 7} \\
{[7.75]^{* *}}\end{array}$ & $\begin{array}{r}\mathbf{- 0 . 6 9} \\
{[6.70]^{* *}}\end{array}$ & $\begin{array}{r}\mathbf{- 0 . 4 7} \\
{[2.32]^{*}}\end{array}$ & $\begin{array}{r}\mathbf{0 . 2 7} \\
{[0.83]}\end{array}$ \\
\hline Eastern Siberian and Far Eastern & $\begin{array}{r}\mathbf{- 0 . 1 6} \\
{[0.97]} \\
\end{array}$ & $\begin{array}{r}\mathbf{0 . 1 4} \\
{[0.78]} \\
\end{array}$ & $\begin{array}{r}\mathbf{- 0 . 2 8} \\
{[1.88]} \\
\end{array}$ & $\begin{array}{r}\mathbf{- 0 . 3 6} \\
{[2.68]^{* *}} \\
\end{array}$ & $\begin{array}{r}\mathbf{- 0 . 2 1} \\
{[1.01]} \\
\end{array}$ & $\begin{array}{r}\mathbf{- 0 . 0 8} \\
{[0.33]} \\
\end{array}$ \\
\hline Constant & $\begin{array}{c}\mathbf{3 . 6 8} \\
{[21.00] * *}\end{array}$ & $\begin{array}{r}\mathbf{4 . 2 3} \\
{[10.97]^{* *}} \\
\end{array}$ & $\begin{array}{r}\mathbf{3 . 7 4} \\
{[21.10] * *} \\
\end{array}$ & $\begin{array}{r}\mathbf{4 . 1 0} \\
{[25.98]^{* *}} \\
\end{array}$ & $\begin{array}{r}\mathbf{3 . 5 6} \\
{[12.16] * *} \\
\end{array}$ & $\begin{array}{r}\mathbf{3 . 5 2} \\
{[10.64]^{* *}} \\
\end{array}$ \\
\hline $\begin{array}{l}\text { Observations } \\
\text { R-squared } \\
\text { Robust } t \text { statistics in brackets }\end{array}$ & $\begin{array}{c}55098 \\
0.45\end{array}$ & $\begin{array}{r}14262 \\
0.43\end{array}$ & $\begin{array}{r}13597 \\
0.51\end{array}$ & $\begin{array}{r}12082 \\
0.52\end{array}$ & $\begin{array}{r}9255 \\
0.48\end{array}$ & $\begin{array}{r}5888 \\
0.33\end{array}$ \\
\hline
\end{tabular}

* significant at 5\%; ** significant at $1 \%$

Source: Authors' estimates 


\section{Table 9. Data Reconciliation and the Welfare Impacts of WTO Accession}

\begin{tabular}{|c|c|c|c|c|c|c|c|}
\hline & & $\begin{array}{l}\text { Skilled } \\
\text { Wages }\end{array}$ & $\begin{array}{r}\text { Unskilled } \\
\text { Wages }\end{array}$ & \begin{tabular}{r|} 
Return to \\
Capital
\end{tabular} & $\begin{array}{r}\text { Taxes and } \\
\text { Transfers }\end{array}$ & $\begin{array}{l}\text { Goods } \\
\text { Prices }\end{array}$ & $\begin{array}{r}\text { Aggregate } \\
\text { EV }\end{array}$ \\
\hline Factor Price Impacts & $\begin{array}{l}\text { Sequential approach a/ } \\
\text { Integrated Model }\end{array}$ & $\begin{array}{l}5.1 \\
5.3\end{array}$ & $\begin{array}{l}3.0 \\
3.7\end{array}$ & $\begin{array}{l}4.9 \\
1.8\end{array}$ & & & \\
\hline \multirow[t]{2}{*}{ Decile $1(0-10 \%)$ - overall } & Sequential approach & 5.3 & 2.2 & 0.2 & -0.5 & 0.0 & 7.2 \\
\hline & Integrated Model & 5.4 & 2.8 & 0.1 & -0.3 & 0.3 & 7.6 \\
\hline \multirow[t]{2}{*}{ Decile $2(11-20 \%)$ - overall } & Sequential approach & 5.3 & 2.0 & 0.3 & -0.4 & 0.0 & 7.3 \\
\hline & Integrated Model & 5.5 & 2.5 & 0.1 & -0.3 & 0.3 & 7.6 \\
\hline \multirow[t]{2}{*}{ Decile 3 (21-30\%) - overall } & Sequential approach & 5.8 & 1.7 & 0.5 & -0.5 & -0.1 & 7.6 \\
\hline & Integrated Model & 5.9 & 2.2 & 0.2 & -0.3 & 0.2 & 7.7 \\
\hline \multirow[t]{2}{*}{ Decile $4(31-40 \%)$ - overall } & Sequential approach & 5.8 & 1.6 & 0.6 & -0.4 & -0.1 & 7.6 \\
\hline & Integrated Model & 5.9 & 2.0 & 0.2 & -0.3 & 0.2 & 7.7 \\
\hline \multirow[t]{2}{*}{ Decile $5(41-50 \%)$ - overall } & Sequential approach & 5.7 & 1.5 & 0.9 & -0.4 & -0.1 & 7.8 \\
\hline & Integrated Model & 5.9 & 1.8 & 0.3 & -0.3 & 0.1 & 7.7 \\
\hline \multirow[t]{2}{*}{ Decile $6(51-60 \%)$ - overall } & Sequential approach & 5.6 & 1.4 & 1.2 & -0.5 & -0.1 & 7.9 \\
\hline & Integrated Model & 5.8 & 1.7 & 0.5 & -0.3 & 0.1 & 7.5 \\
\hline \multirow[t]{2}{*}{ Decile 7 (61-70\%) - overall } & Sequential approach & 5.7 & 1.1 & 1.6 & -0.5 & -0.1 & 8.1 \\
\hline & Integrated Model & 5.8 & 1.4 & 0.6 & -0.3 & 0.0 & 7.5 \\
\hline \multirow[t]{2}{*}{ Decile 8 (71-80\%) - overall } & Sequential approach & 5.9 & 0.9 & 1.9 & -0.5 & -0.1 & 8.4 \\
\hline & Integrated Model & 6.0 & 1.2 & 0.7 & -0.4 & 0.1 & 7.5 \\
\hline \multirow[t]{2}{*}{ Decile $9(81-90 \%)$ - overall } & Sequential approach & 5.1 & 0.9 & 2.6 & -0.5 & -0.2 & 8.3 \\
\hline & Integrated Model & 5.3 & 1.1 & 1.0 & -0.3 & -0.1 & 7.2 \\
\hline \multirow[t]{2}{*}{ Decile $10(91-100 \%)$ - overall } & Sequential approach & 4.4 & 0.6 & 3.8 & -0.5 & 0.0 & 8.3 \\
\hline & Integrated Model & 4.5 & 0.8 & 1.4 & -0.3 & -0.3 & 6.8 \\
\hline
\end{tabular}

a/ The Sequential approach is also called "open loop" or "top-down" approach. The integrated model is also called "closed loop" or "bottom-up" approach.

Source: Authors' estimates 
Table 10. Impact of Household Aggregation on Estimated Welfare Effects of WTO Accession at the Decile Level ${ }^{\mathrm{a} /}$

(welfare change as a percent of consumption)

\begin{tabular}{|c|c|c|c|c|}
\hline & \multicolumn{4}{|c|}{ Number of Households in Model } \\
\hline & $\mathrm{N}=10$ & $\mathrm{~N}=70$ & $\mathrm{~N}=950$ & $\mathrm{~N}=55120$ \\
\hline Decile $1(0-10 \%)$ & 7.6 & 7.6 & 7.6 & 7.6 \\
\hline Decile $2(11-20 \%)$ & 7.6 & 7.6 & 7.6 & 7.6 \\
\hline Decile $3(21-30 \%)$ & 7.7 & 7.7 & 7.7 & 7.7 \\
\hline Decile $4(31-40 \%)$ & 7.7 & 7.7 & 7.7 & 7.7 \\
\hline Decile $5(41-50 \%)$ & 7.6 & 7.6 & 7.6 & 7.7 \\
\hline Decile $6(51-60 \%)$ & 7.5 & 7.5 & 7.5 & 7.5 \\
\hline Decile $7(61-70 \%)$ & 7.5 & 7.5 & 7.5 & 7.5 \\
\hline Decile $8(71-80 \%)$ & 7.5 & 7.5 & 7.5 & 7.5 \\
\hline Decile $9(81-90 \%)$ & 7.2 & 7.2 & 7.2 & 7.2 \\
\hline Decile $10(91-100 \%)$ & 6.8 & 6.8 & 6.7 & 6.8 \\
\hline
\end{tabular}

${ }^{a}$ Four versions of the model are executed, where in three versions, households from the HBS are aggregated into either 10,70 or 950 households. Decile 1 is comprised of the ten percent poorest households on a per capita basis. In models with $\mathrm{N}>10$, a weighted average of the equivalent variation for the households in the decile produced the result in the table for the decile.

Source: Authors' estimates 
Table 11: Piecemeal Sensitivity Analysis-Welfare effects

\begin{tabular}{|c|c|c|c|c|c|c|}
\hline \multirow[b]{2}{*}{ Parameter $^{\mathrm{a}}$} & \multicolumn{3}{|c|}{ Parameter value } & \multicolumn{3}{|c|}{$\begin{array}{l}\text { Hicksian equivalent variation with } \\
\text { corresponding parameter }\end{array}$} \\
\hline & Lower & $\begin{array}{l}\text { Inter- } \\
\text { mediate }\end{array}$ & Upper & Lower & $\begin{array}{r}\text { Inter- } \\
\text { mediate }\end{array}$ & Upper \\
\hline esubs & 0.5 & 1.25 & 2 & 5.6 & 7.3 & 9.9 \\
\hline esub & 2 & 3 & 4 & 7.4 & 7.3 & 6.9 \\
\hline sigmadm & 2 & 3 & 4 & 7.2 & 7.3 & 7.4 \\
\hline esubprimary & 0.7 & 1 & 1.3 & 7.2 & 7.3 & 7.3 \\
\hline esubintermed & 0 & 0 & 0.25 & 7.3 & 7.3 & 7.6 \\
\hline etadx & 3 & 5 & 7 & 7.2 & 7.3 & 7.3 \\
\hline etad & 5 & 7.5 & 10 & 6.9 & 7.3 & 7.6 \\
\hline etaf & 10 & 15 & 20 & 5.2 & 7.3 & 8.8 \\
\hline theta_m(i) & \multicolumn{3}{|c|}{ see table below } & 7.2 & 7.3 & 7.4 \\
\hline theta_fdi(i) & \multicolumn{3}{|c|}{ see table below } & 5.3 & 7.3 & 8.5 \\
\hline
\end{tabular}

a The piecemeal sensitivity analysis employs central values for all parameters (see below) other than the tested parameter and lump sum tax replacement.

${ }^{b}$ Hicksian equivalent variation as a percent of the value of consumption in the benchmark equilibrium.

Key:

\begin{tabular}{lcl}
\hline Parameter & Central & Definitions of the parameter \\
\hline esubs & value & \\
esub & 1.25 & Elasticity of substitution between value-added and business services \\
sigmadm & 3 & Elasticity of substitution between firm varieties in imperfectly competitive sectors \\
esubprimary & 3 & "Armington" elasticity of substitution between imports and domestic goods in CRTS sectors \\
esubinterme & 1 & Elasticity of substitution between primary factors of production in value added \\
esubconsum & 1 & Elasticity of substitution in intermediate production between composite Armington aggregate goods \\
Etadx & 5 & Elasticity of substitution in consumer demand \\
Etad & 7.5 & Elasticity of transformation (domestic output versus exports) \\
Etaf & 15 & Elasticity of Russian service firm supply with respect to price of output \\
theta_m(i) & varies & share of specialized imports V as a share of value added in multinational firms in sector I in the benchmark equilibrium \\
theta_fdi(i) & varies & share of output of service sector I captured by multinationals firms in the benchmark equilibrium \\
\hline
\end{tabular}

\begin{tabular}{l|ccc|ccc}
\hline Parameter values for: & \multicolumn{3}{|c|}{ theta_fdi(i) } & \multicolumn{3}{c}{ theta_m(i) } \\
\hline & low & central & high & low & central & high \\
railway transportation & 0.01 & 0.03 & 0.05 & 0.02 & 0.04 & 0.06 \\
truck transportation & 0.03 & 0.05 & 0.07 & 0.01 & 0.03 & 0.05 \\
pipelines transportation & 0.01 & 0.03 & 0.05 & 0.05 & 0.1 & 0.15 \\
maritime transportation & 0.25 & 0.35 & 0.4 & 0.01 & 0.03 & 0.05 \\
air transportation & 0.15 & 0.25 & 0.35 & 0.1 & 0.125 & 0.15 \\
other transportation & 0.02 & 0.04 & 0.06 & 0.03 & 0.05 & 0.07 \\
telecommunications & 0.05 & 0.15 & 0.25 & 0.08 & 0.1 & 0.12 \\
science and science & & & & & & \\
servicing (market) & 0.05 & 0.1 & 0.15 & 0.1 & 0.15 & 0.2 \\
financial services & 0.05 & 0.1 & 0.15 & 0.01 & 0.03 & 0.05 \\
\hline
\end{tabular}

Source: Authors' estimates 


\section{Figure 1: Production and Allocation of Output}

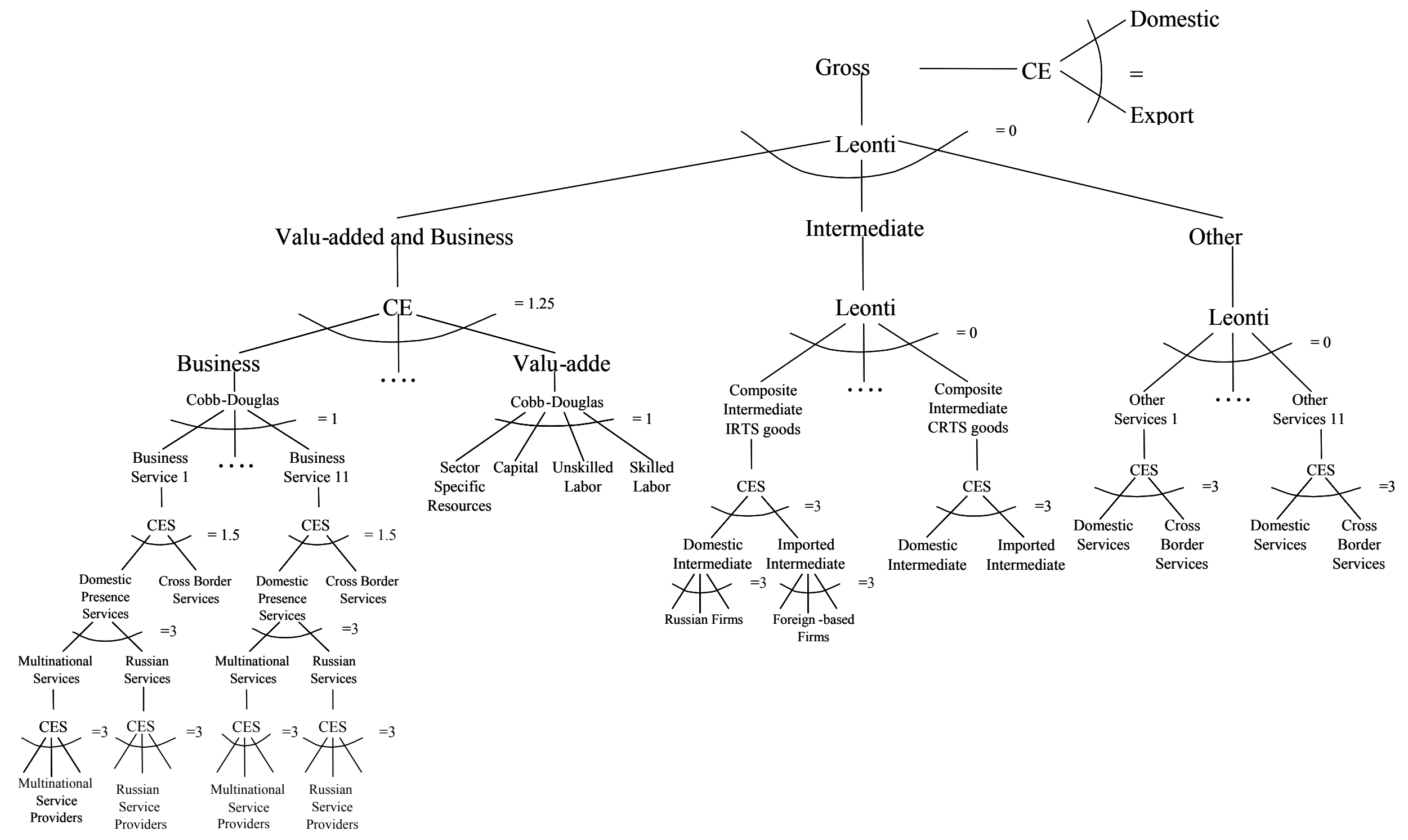




\section{Figure 2A: Two Good Illustration of our SolutionAlgorithm--Step 1}

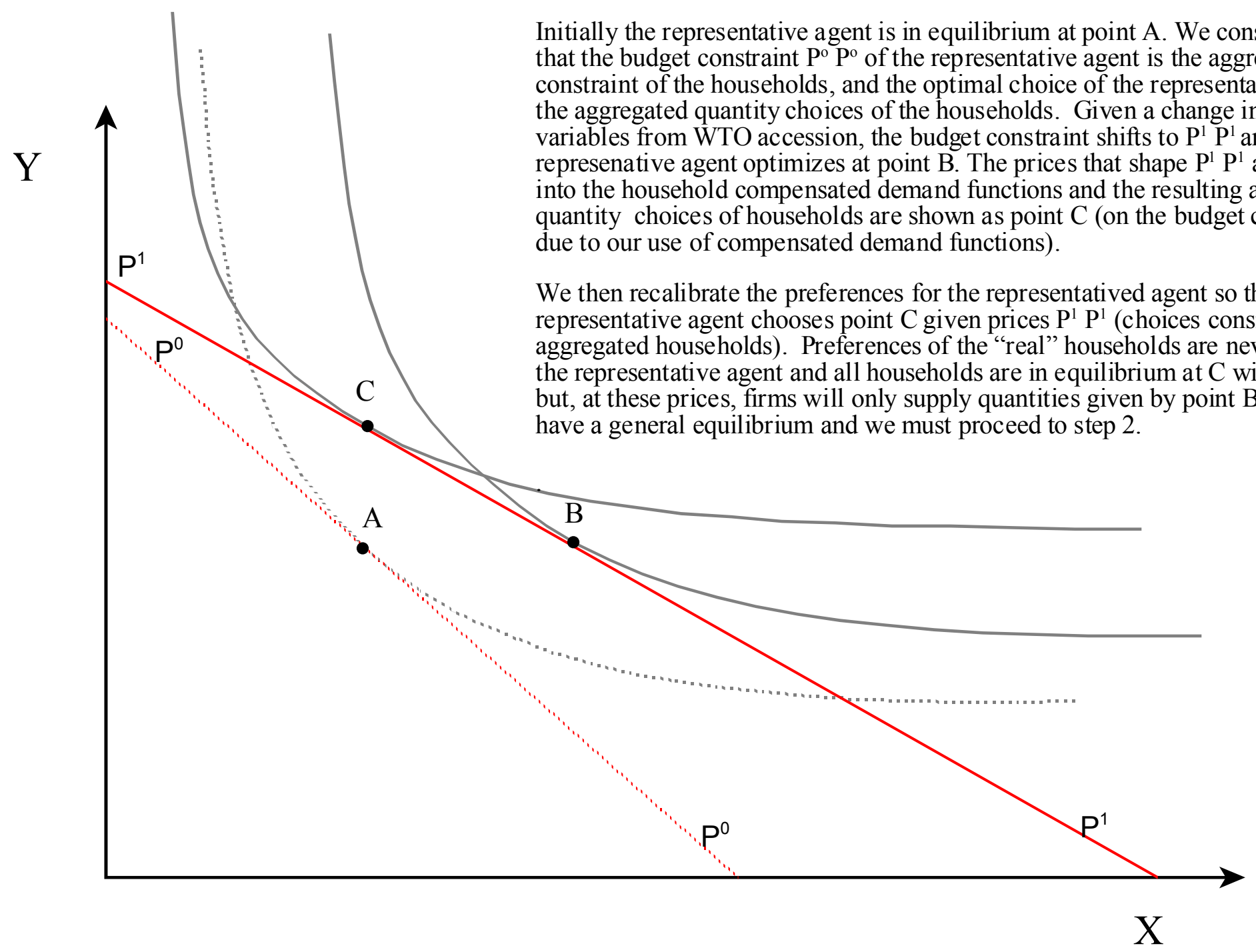




\section{Figure 2B: Two Good Illustration of our SolutionAlgorithm--Step 2}

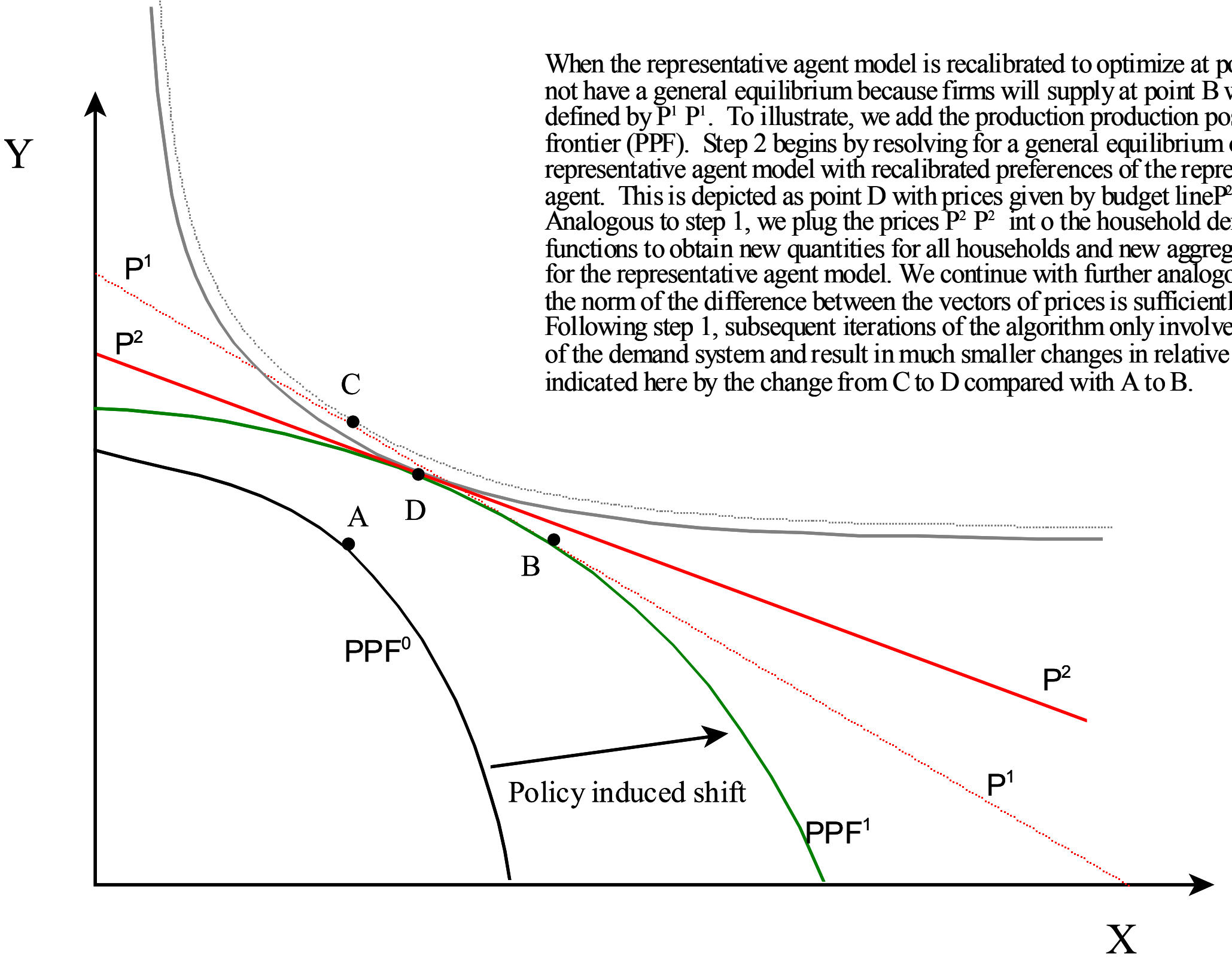


Figure 3. Distributions of the estimated welfare gains from Russian WTO accession for the entire sample and the poorest quarter.

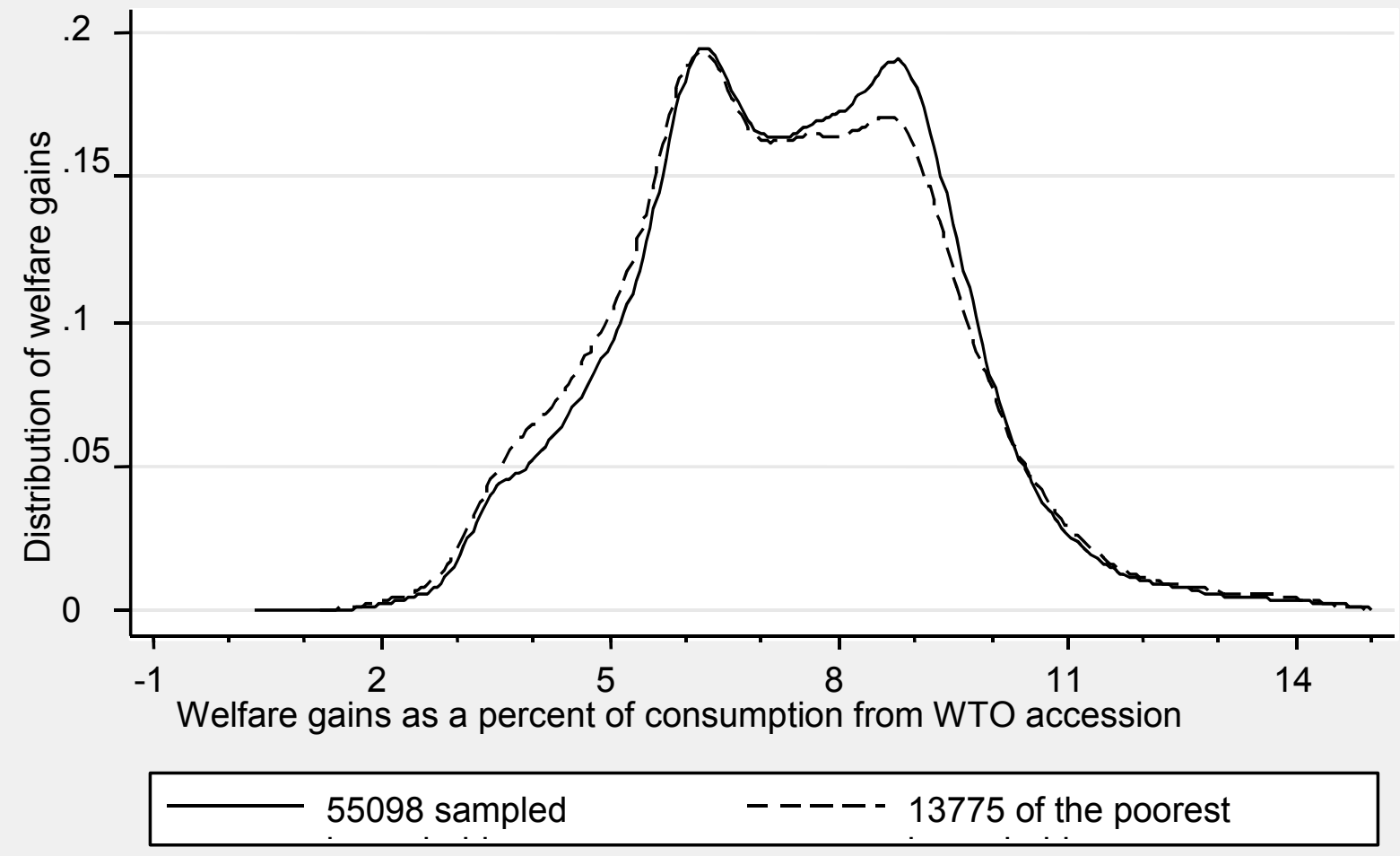

Only observations with percentage welfare gains from $0 \%$ to $15 \%$ are shown.

Figure 4. Distributions of estimated welfare gains from Russian WTO accession.
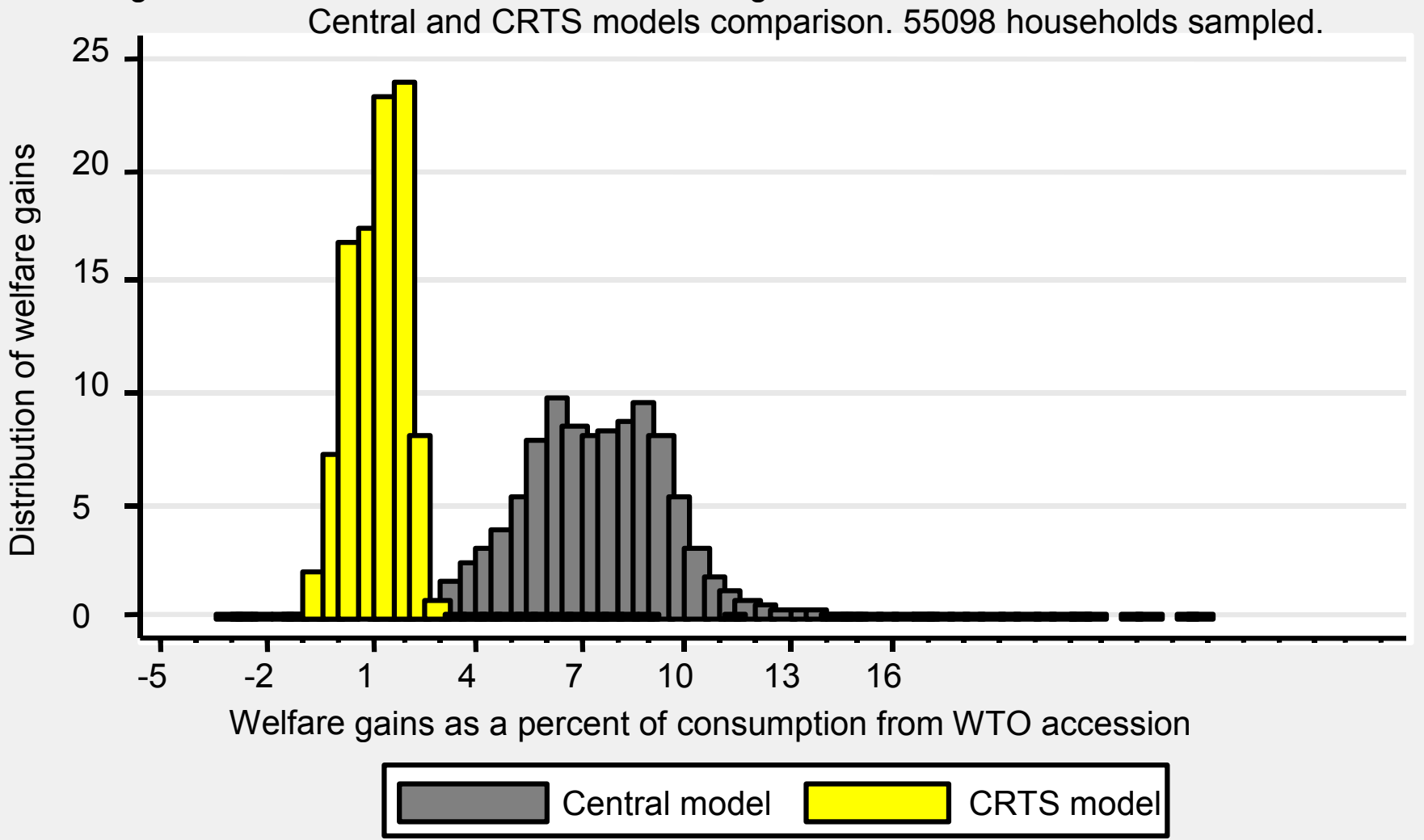

Onlv observations with a percentage welfare gains between $5 \%$ and $25 \%$ are shown. 
Figure 5: Distribution of welfare results by income decile (all households)

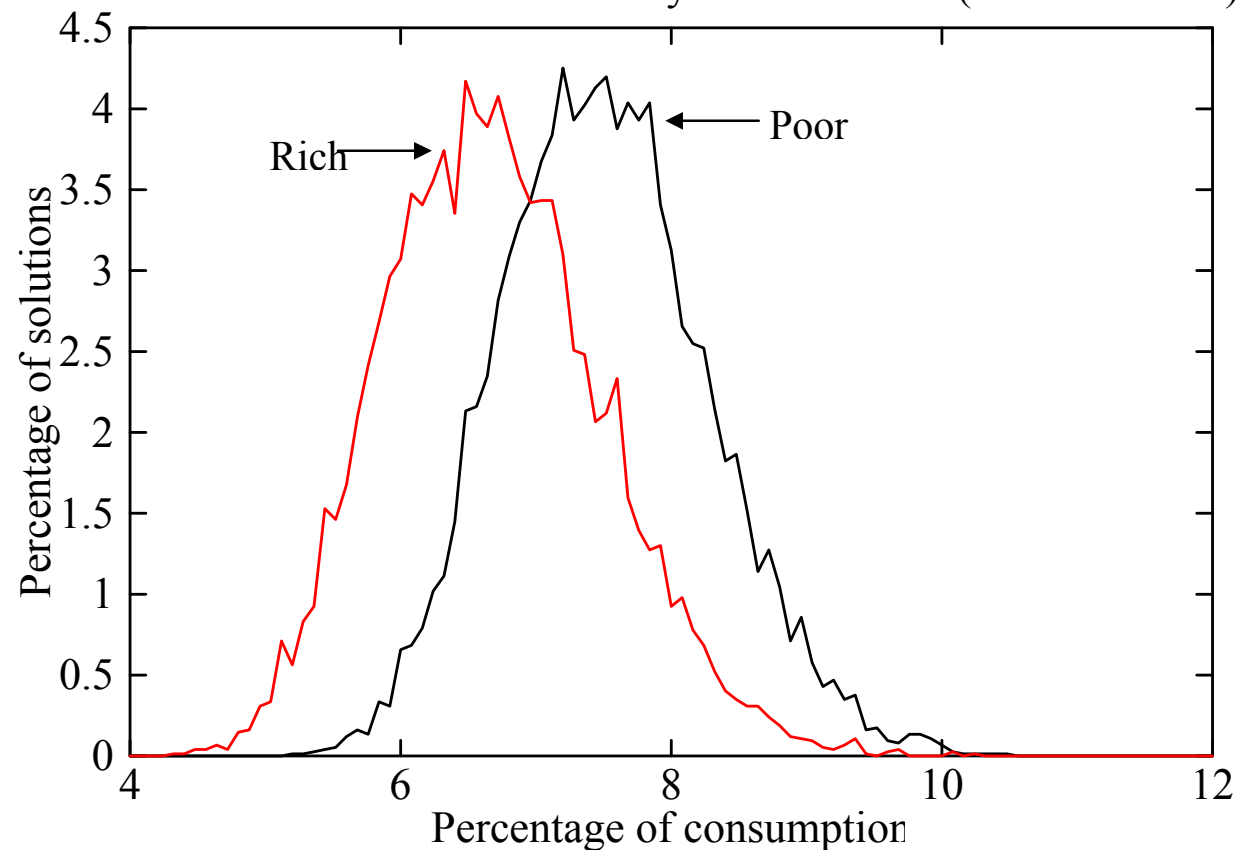

95\% confidence intervals (assuming a normal distribution): Poor (6.1, 9.0), Rich (5.1, $8.3)$.

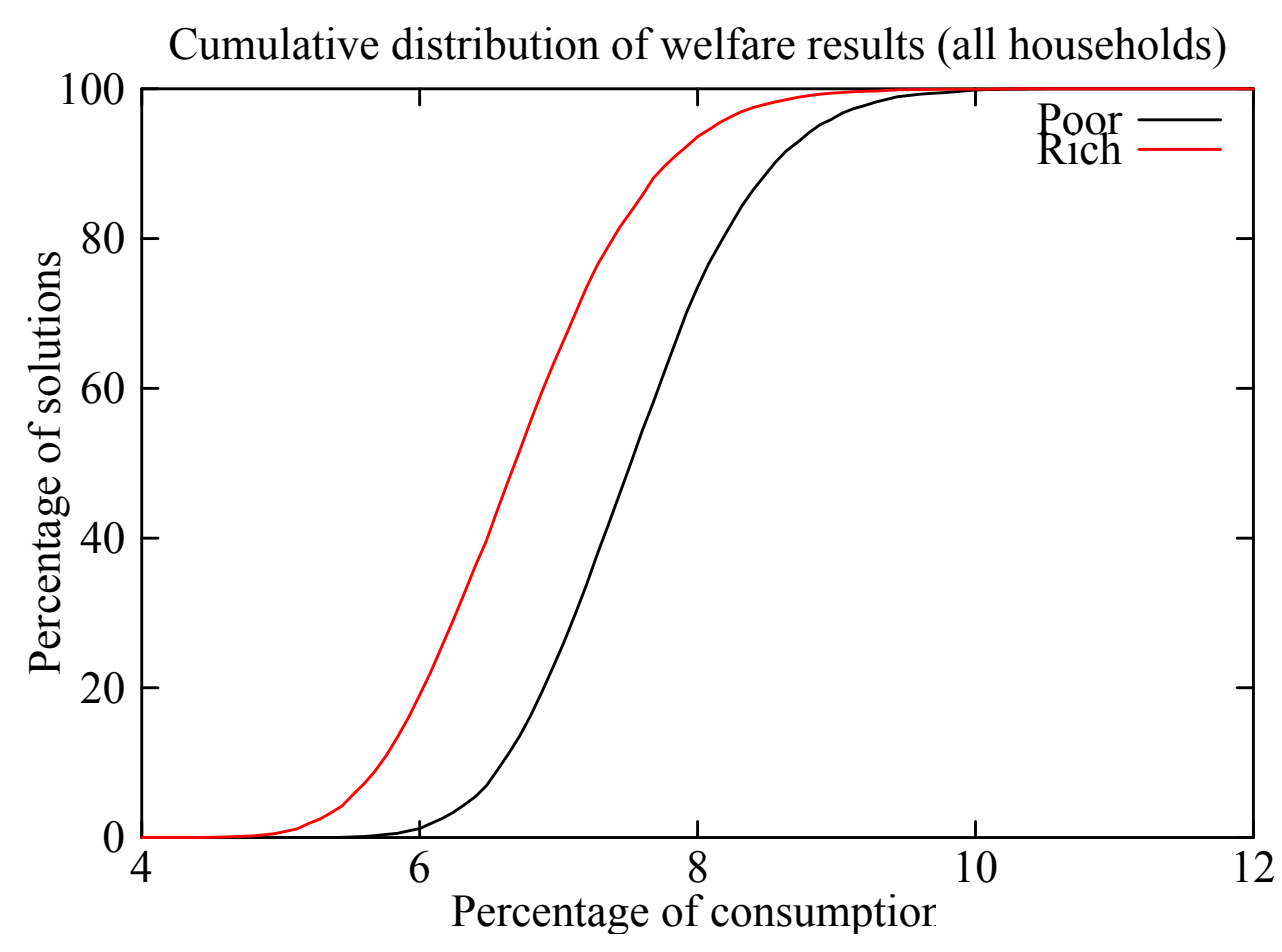




\section{Appendix A: Description of the GAMS Code for Solving Models with a Very Large Number of Agents}

In this appendix we describe a small GAMS program which formulates a simple exchange model with multiple households and shows how the model can be solved either in "bottom-up" mode (with an explicit representation of the consumer demands in the model) or through successive computation of a "top-down" model. ThE GAMS code follows:

\$title A Successive Recalibration Algorithm for GE Models with Many Households

\$ontext

This program constitutes explicit documentation of the solution algorithm used to solve a general equilibrium model of the economic effects of Russia's accession to the WTO based on Goskomstat's consumer expenditure survey. That model has 55094 households. For further details, see the working paper:

Poverty Effects of Russia's WTO Accession: modeling "real" households and endogenous productivity effects

Thomas Rutherford, University of Colorado

David Tarr, The World Bank

Oleksandr Shepotylo, University of Maryland

September, 2004

Contact: dtarr@worldbank.org

The default configuration of this model has 1000 households. The program output is the reporting parameter itrlog which should be displayed as follows:

---- 459 PARAMETER itrlog Equilibrium price levels 


$\begin{array}{lrllccccl} & \text { bottomup } & \text { iter0 } & \text { iter1 } & \text { iter2 } & \text { iter3 } & \text { iter4 } & \text { iter5 } & \\ \text { i1 } & 0.96239 & 0.95735 & 0.96309 & 0.96230 & 0.96241 & 0.96239 & 0.96239 \\ \text { i2 } & 0.99602 & 0.99546 & 0.99607 & 0.99601 & 0.99602 & 0.99602 & 0.99602 \\ \text { i3 } & 1.00449 & 1.00511 & 1.00439 & 1.00451 & 1.00449 & 1.00450 & 1.00449 \\ \text { i4 } & 1.05347 & 1.05983 & 1.05275 & 1.05355 & 1.05346 & 1.05347 & 1.05347 \\ \text { i5 } & 0.98992 & 0.98869 & 0.99005 & 0.98990 & 0.98992 & 0.98992 & 0.98992 \\ \text { i6 } & 1.01483 & 1.01677 & 1.01456 & 1.01487 & 1.01483 & 1.01483 & 1.01483 \\ \text { i7 } & 1.00364 & 1.00420 & 1.00353 & 1.00365 & 1.00363 & 1.00364 & 1.00364 \\ \text { i8 } & 0.93811 & 0.93088 & 0.93903 & 0.93800 & 0.93813 & 0.93811 & 0.93812 \\ \text { i9 } & 1.02511 & 1.02800 & 1.02476 & 1.02515 & 1.02510 & 1.02511 & 1.02511 \\ \text { i10 } & 1.01202 & 1.01371 & 1.01176 & 1.01206 & 1.01201 & 1.01202 & 1.01202\end{array}$

\section{$\begin{array}{llllllll}\text { CPU } & 0.36100 & 0.03000 & 0.04000 & 0.03000 & 0.03000 & 0.03000 & 0.02000\end{array}$ delta $\quad \begin{array}{llllll}0.25639 & 0.03186 & 0.00407 & 0.00052 & 0.000078 .740106 \mathrm{E}-6\end{array}$}

Rows labelled i1 to i10 report equilibrium prices from various models. "bottomup" presents equilibrium prices for the integrated model in which each of the households is explicitly modelled. The columns labelled "iter0", "iter1", etc. report equilibrium prices returned for successive steps in the approximation procedure. Notice that the bottom up model agrees to five decimals the last three iterations of the decomposition procedure.

The row labelled "CPU" reports elapsed time (calculated using the GAMS internal function "system.timeexec") required to process each of the models. (Notice that even with as few as 1000 households, the decomposition procedure is much faster than the integrated bottom-up model.)

The row labelled "delta" reports the computed deviation at each step in the decomposition procedure. This deviation is the 1-norm of changes in computed equilibrium prices from one iteration to the next. The decomposition algorithm is terminated when delta falls below 1e-5

\$offtext 
* Define the dimensions of the model here:

\$if not set nhh \$set nhh 1000

$\begin{array}{lll}\text { set } & \mathrm{h} & \text { Households } / \mathrm{h} 1{ }^{*} \mathrm{~h} \% \mathrm{nhh} \% / \text {, } \\ & \text { i } & \text { Commodities } / \mathrm{i} 1^{*} \mathrm{i} 10 / ;\end{array}$

alias $(i, j)$;

* Use randomly generated input data:

parameterc $0(\mathrm{i}, \mathrm{h}) \quad$ Reference consumption levels, e0(i,h) Commodity endowments,

timestart Run time

sigma(h) Elasticities of substitution in demand;

$\mathrm{c} 0(\mathrm{i}, \mathrm{h})=$ uniform $(0,1)$;

$\mathrm{e} 0(\mathrm{i}, \mathrm{h})=$ uniform $(0,1)$;

$\operatorname{sigma}(\mathrm{h})=$ uniform $(0.25,2)$;

* Avoid the tedium of coding both Cobb-Douglas and CES

* demand functions:

$\operatorname{sigma}(\mathrm{h}) \$(\operatorname{abs}(\operatorname{sigma}(\mathrm{h})-1)<0.01)=0.99$;

display c0, e0, sigma;

* Declare and solve a model with a fully disaggregate

* set of households:

\$ontext

\$model:bottomup

\$commodities:

$\mathrm{p}(\mathrm{i})$ 
\$consumers:

$\mathrm{hh}(\mathrm{h})$

\$demand:hh(h) s:sigma(h)

e:p(i) $\quad q: e 0(i, h)$

d:p(i) $\quad q: c 0(i, h)$

\$offtext

\$sysinclude mpsgeset bottomup

* When an MPSGE model is formulated with high dimensionality, it is

* often necessary to manually increase the allocated workspace. Here

* I am allocating 50 megabytes to the workspace array, a value which

* is adequate for more than 10,000 households:

bottomup. workspace $=50$;

* Solve the bottom-up model in a single shot:

timestart = system .timeexec;

\$include bottomup.gen

solve bottomup using mcp;

parameteritrlog $\left({ }^{*},{ }^{*}\right)$ Equilibrium price levels;

itrlog("CPU","bottomup") = system.timeexec - timestart;

itrlog(i,"bottomup") = p.I(i) * $\operatorname{card}(\mathrm{i}) / \operatorname{sum}(\mathrm{j}, \mathrm{p} . \mathrm{I}(\mathrm{j}))$;

* Next, solve the same model recursively using the

* successive recalibration algorithm:

* The top-down model is based on a single representative

* $\quad$ agent whose preferences are successively adjusted to

* $\quad$ locally portray the "community indifference curve" which

* describes the underlying household endowments and preferences: 
parametertheta(i,h) Household benchmark budget shares, Household consumption price index, Household utility index (relative to $\mathrm{c} 0$ ),

pref(i) Reference price cref(i)

Reference demand quantity;

* Compute the benchmark budget shares:

theta $(\mathrm{i}, \mathrm{h})=\mathrm{c} 0(\mathrm{i}, \mathrm{h}) / \operatorname{sum}(\mathrm{j}, \mathrm{c0}(\mathrm{j}, \mathrm{h}))$;

* Initially calibrate the community indifference curve

* based on a price point at the center of the simplex:

$\mathrm{u}(\mathrm{h}) \quad=\operatorname{sum}(\mathrm{i}, \mathrm{e} 0(\mathrm{i}, \mathrm{h})) / \operatorname{sum}(\mathrm{i}, \mathrm{cO}(\mathrm{i}, \mathrm{h}))$;

$\operatorname{cref}(i)=\operatorname{sum}(h, c 0(i, h) * u(h))$;

$\operatorname{pref}(\mathrm{i})=1$;

* Here is the top-down model. Note that the h set does

* $\quad$ not appear in this model:

\$ontext

\$model:topdown

\$commodities:

p(i) ! Commodity prices

\$consumers:

ra ! Reprsentative agent:

* Preferences are Cobb-Douglas:

\$demand:ra s:1

$$
\begin{array}{ll}
\text { e:p(i) } & \text { q:(sum(h,e0(i,h))) } \\
d: p(i) & q: \operatorname{cref}(i) \quad p: p r e f(i)
\end{array}
$$

\$offtext

\$sysinclude mpsgeset topdown 
* $\quad$ Fix aggregate income to normalize the price system:

ra.fx $=\operatorname{sum}(h, h h . l(h))$;

set iter Iterations in the projection algorithm /iter0*iter10/;

parameterdelta Convergence metric /1/;

* Loop until we have drive the sum of absolute price changes

* to a small level:

loop $($ iter $\$($ delta $>1 e-5)$,

* Within each iteration we solve the top-down model. Note that

* each solution is very cheap because the model is small and the

* previous iteration's solution is already in place:

timestart $=$ system $\cdot$ timeexec;

Sinclude topdown.gen

solve topdown using mcp;

itrlog("CPU",iter) = system.timeexec - timestart;

* Record the current deviation:

delta $=\operatorname{sum}(i, \operatorname{abs}(p . I(i)-p r e f(i))) ;$

itrlog("delta",iter) = delta;

* $\quad$ Update the iteration log:

itrlog(i,iter $)=p . I(i){ }^{*} \operatorname{card}(i) / \operatorname{sum}(j, p . I(j))$;

* Recalibrate preferences of the representative agent based on

* demands of the individual households: 


$$
\operatorname{pc}(\mathrm{h})=\operatorname{sum}\left(\mathrm{i}, \text { theta }(\mathrm{i}, \mathrm{h}){ }^{*} \mathrm{p} . \mathrm{I}(\mathrm{i})^{* *}(1-\operatorname{sigma}(\mathrm{h}))\right)^{* *}(1 /(1-\operatorname{sigma}(\mathrm{h}))) \text {; }
$$

* Utility index for household $\mathrm{h}$ (relative to $\mathrm{c0}$ ):

$u(h)=\operatorname{sum}\left(i, e 0(i, h)^{*} p . l(i)\right) /\left(p c(h)^{*} \operatorname{sum}(i, c 0(i, h))\right) ;$

* Reference consumption level for the representative agent:

$\operatorname{cref(i)}=\operatorname{sum}\left(\mathrm{h}, \mathrm{cO}(\mathrm{i}, \mathrm{h}){ }^{*} \mathrm{u}(\mathrm{h}){ }^{*}(\mathrm{pc}(\mathrm{h}) / \mathrm{p} . \mathrm{I}(\mathrm{i}))^{* *} \operatorname{sigma}(\mathrm{h})\right) ;$

$\operatorname{pref}(i)=p . I(i)$;

);

option itrlog:5;

display itrlog; 


\section{Appendix B: Estimation on Factor Income Shares for the Household Budget Survey of Russia.}

Experience with trade policy models that examine household impacts has shown that the impact on household income is most strongly affected by changes in wages and payments to other factors of production. Thus, it is crucial in an assessment of the impact of WTO accession on Russian household welfare to determine the sources of household income. There are three input factors in the numerical general equilibrium model: unskilled labor, skilled labor, and capital. Trade policy changes will differ across industries and industries use factors in different proportions. Therefore, returns to input factors will also be affected differently. If for example as a result of WTO accession the wage rate of unskilled workers will increase because of expansion of the sectors that are unskilled labor intensive, then the households that earn a larger proportion of their income from unskilled labor will benefit more. In addition, given the concerns about regional impacts of WTO accession, we seek estimates of factor shares that differ according to the region of Russia.

To calculate factor income shares in the model, two datasets have been used: the Household Budget Survey (HBS) and the Russian Longitude Monitoring Survey (RLMS). The HBS has 55,000 household observations and is representative at the regional level. In order for us to assess household impacts at the regional level we will have to employ the HBS. The HBS has very detailed information on the household consumption expenditures, and information about age, gender, education, primary, secondary, and other occupation of each member of the household. It also has derived information about total income of the household as the sum of household expenditures and savings.

The major shortcoming of the HBS for our purposes is that we do not have information from it on the sources of income of the households. For sources of household income, we must 
turn to the RLMS. The RMLS has less than 5,000 observations and is not representative of the population on the regional level (such as oblast, krai or republic). But is has extensive information on individual and household sources of income: wages and profits from first, second, third jobs; pensions and unemployment benefits; profits and dividends from accumulated assets. In this note, we explain how we combine information from the two surveys to generate factor shares for the households in the HBS.

Recent advances in the literature have proposed techniques for combining data from different data sources. Econometric techniques as small area estimation (SAE) and matching have been proposed to produce synthetic datasets that combine survey data with comprehensive census information. For a literature review on different SAE model see Rao (1999). Properties of small area statistics are also discussed in Nordbotten (1999). A useful application is by Elbers, Lanjouw, and Lanjouw (2003), who applied the small area estimation technique to study the effect of policy changes on welfare measures for Ecuador. They show that their estimated welfare measures are reliable (small variance of the estimator) for populations as small as 15,000 households. An alternative to $\mathrm{SAE}$ is the matching technique based on propensity scores. Matching is discussed in Moriarity and Scheuren (2003)

\section{Mapping the Data.}

First, we chose characteristics of the two datasets that are common to both and which we expect influence factor shares of income. These characteristics, which can be found in both the HBS and the RLMS, are:

- Personal characteristics: age, gender (1-male, 2-female), skilled (0-unskilled, 1-skilled), head of the household (1-headhh), primary, secondary, and other occupation, and income. 
- Household characteristics: family size, members of the household who work

- Geographic characteristics of the locality: region, type of settlement: urban/rural.

- Household income

A full explanation of the variables and summary statistics are provided in Table 1. Some variables are directly comparable between the two datasets. This includes data on personal and household characteristics such as age, gender, composition of the household. But there are differences between the datasets in geographical representation, reported occupation, and the income of households. These differences can be explained by the differences in sampling and indirectly to the differences in survey designs. For example, in order to reduce the costs of faceto-face interviews, geographically inaccessible regions are underrepresented in the RLMS dataset. In particular, the geographically biggest East Siberia and Far East region is underrepresented in the RLMS sample ${ }^{21}$.

In order to make some of the variables comparable between the surveys, we transformed the raw data in some cases. For example, there is only one question on education in the HBS: what is your level of education? The RLMS, on the other hand, has a number of questions on education, such as the level of education, the number of years studied, whether the individual received a diploma or not, and whether the individual attended professional courses while working or not. Therefore, it was necessary to combine the various educational measures in the RMLS into one summary measure in order to produce a comparable variable.

\footnotetext{
${ }^{21}$ RLMS sampling procedure is discussed at http://www.cpc.unc.edu/projects/rlms/project/sampling.html
} 
In addition, the questions that are posed in the two surveys regarding primary, secondary

and other occupation of household members are not identical in the two surveys. Thus, there may

be some differences in responses across the surveys due to the framing of the questions.

\section{Factor income shares: RLMS.}

The RLMS contains data on both households and individuals, and both sets of information were employed. The individual (adult) survey has the information on individual income sources and contains around 10,500 observations. The household survey has around 4,500 households. Each individual respondent can be traced to a particular household in the household survey, making it possible to merge these two datasets. We used individual surveys to calculate income from primary and secondary place of employment, pensions, unemployment benefits and from additional (self-employed) work, such as selling goods in a market, doing construction or repair work and providing transportation services in one's personal vehicle. From the household surveys we obtained information on household characteristics.

First, we classified all individuals according to their primary, secondary, and other occupation to make it comparable with the HBS data. If a person had a primary job then she was classified as a worker or entrepreneur based on her answer whether she is an entrepreneur or worker on the primary job. If a person did not have a primary job but received pension or unemployment benefit then she was classified as a pensioner or unemployed. A person who had no primary or secondary job and was not a pensioner or unemployed was defined to be outside of the labor force. The classification according to the secondary occupation was done analogously. A person was considered as a worker or entrepreneur if she had second job and classified herself as a worker or entrepreneur. A small number of individuals (194 out of 128,500) were both workers and entrepreneurs based on this classification system, but whether they were workers or 
entrepreneurs in their primary or secondary jog was also recorded. A person was considered as a working pensioner if she had primary job and also received a pension.

Total individual income can be broken down into primary, secondary, and other sources of income according to occupation. For example, if a person is a pensioner who continues to work then her primary occupation is worker and secondary occupation is pensioner. Her primary source of income is wages, bonuses, profits from primary place of work in the last 30 days (variables i9wagelm and i9goodsv). > i9wagelm Her secondary source of income is pension in the last 30 days (variable i9ampens) and she has no other source of income.

To separate wages from profits and bonuses, we applied the following procedure. If the person is a co-owner of the company, some of her income could be attributed to payments to capital. Also, if a person reported not only wages but also profits and bonuses then part of it could be attributed to the capital. To account for this, we subtracted implied wages from the primary, secondary and other income. Implied wages were calculated as average wage rates depending on skills and location times the number of hours worked that is reported in the survey. Then we can write the following:

labor income $\mathrm{i}_{\mathrm{i}}=$ hoursi $^{*}$ wage rate $($ (skilled, region),

where $\mathrm{i}$ is primary, secondary, or other occupation

hoursi number of hours worked at $\mathrm{i}$

wage ratei(skilled, region) is the average wage rate for occupation i depending on skill status of the worker and region of employment.

The remaining income is attributed to capital earnings.

capital income $e_{i}=$ income from occupation - labor income $_{i},(2)$ 
If hours worked in the primary company owned by the individual are not reported, we assumed that she worked 160 hours $(4 \times 40$ hour working week) minus the time worked in other places. Also, if the person was a pensioner or unemployed we assumed that all her income was labor income because these sources of income are deferred compensation to workers.

\section{Imputation of individual income for HBS.}

The HBS has data on total household income and individual characteristics such as age, education, gender, primary, secondary and other occupation. To exploit individual information to predict factor income shares we have to break down household income into incomes of household members.

Based on the RLMS individual and household income data, we calculated average income shares of household members as a function of the composition of the household (Table 2). We defined the head of the household as a person who has a source of income from primary, secondary, or other occupation and is listed first in the household member list (has the lowest id number). We applied the numbers from Table 2 to calculate individual incomes using the equation 3:

indinc=hhinc ${ }^{*}$ ind_share,

where indinc is individual income, hhinc is total household income less non-working related benefits ${ }^{22}$, ind_share is the share of household income attributed to this individual, which depends

\footnotetext{
22 Household income is defined as household expenditures plus savings minus transfers. Transfers are the sum of housing benefits, gifts, and other non-work related benefits. Also, if no household members had work related source of income then the whole household income was considered as transfers.
} 
on whether the individual in the head of household and the number of people in the household (see Table 2).

\section{Calculation of factor income shares for HBS.}

As the last step, we break down imputed individual incomes into three parts: skilled labor income, unskilled labor income and capital income for each individual in the HBS survey. The person is considered a skilled worker if her educational level goes beyond high school education. ${ }^{23}$ Then, we calculate household factor shares as weighted averages of individual income shares. ${ }^{24}$

Based on the data in the RMLS survey, we run a logit regression of individual labor share on common characteristics for RLMS individuals and use the estimates to predict labor shares for HBS individuals:

$$
\text { lshare }_{i}=\frac{\exp \left(X_{i} \beta\right)}{1+\exp \left(X_{i} \beta\right)}+\varepsilon_{i}
$$

where $\mathrm{X}$ is a vector of personal characteristics and $\beta$ is a vector of coefficients

The choice of a functional form was motivated by the fact that labor share is always positive and bounded between 0 and 1.Also, the relationship between labor share of income and the explanatory variables is potentially highly non-linear. Finally, we are restricted to the set of explanatory variables that are common for both surveys. To improve the power of prediction we divide individuals in quintiles according to individual income and run regression (4) separately for

\footnotetext{
23 Person is a skilled worker if she has technical or higher education.

24 Weights equal to the ratio of individual income to the household income.
} 
each quintile ${ }^{25}$. The results of the regressions by individual income quintiles are presented in Table 3.

Based on the results of Table 3, we estimate the individual factor shares for the HBS sample. With the estimated factor shares for individuals in the HBS, we calculate household factor shares as a weighted average. The imputed factor shares by household income deciles in the HBS are presented in Table 4. It also contains the RLMS sample statistics to compare the results. The differences in skilled labor share are mainly due to the higher proportion of skilled workers in RLMS sample. On the other hand, both surveys agree well on the capital income shares.

As a check on our estimates, we employed a subgroup matching approach to compute factor shares. All workers were divided into subgroups according to the following categories: region, rural/urban, skilled/unskilled, primary occupation, individual income quintile. Then we calculated average labor share for each subgroup using RLMS data and applied it to HBS individuals in the same subcategory:

$a v g_{-}$share $_{i}=\frac{\sum_{k} \text { lshare }_{i k}}{K}$, where $\mathrm{K}$ is the number of RLMS people in the subcategory $\mathrm{i}$.

The results of imputation of factor shares by household income deciles using the subgroup matching approach are presented in Table 5. The results are remarkably close to the regression results. The main difference is that the unskilled labor share is slightly higher and capital's share is slightly lower with the regression approach. We employ the results from the regression approach in our model.

\footnotetext{
25 We did not run regression for the first quintile but rather assumed that labor share is 1 for all individuals because there are no observations with labor share different from 1 in the RLMS.
} 
Literature.

1. Moriarity, C. and F. Scheuren (2003), “A Note on Rubin's Statistical Matching Using File Concatenation with Adjusted Weights and Multiple Imputations," Journal of Business and Economic Statistics Jan 2003 pp.65-73.

2. Rao, J.N.K. (1999), "Some Recent Advances in Model-Based Small Area Estimation," Survey Methodology, December Vol. 25, No. 2, pp 175-186.

3. Elbers, C., Lanjouw, J.O., and P. Lanjouw (2003), "Micro-level Estimation of Poverty and Inequality". Econometrica v71, n1 (January 2003): 355-64 


\begin{tabular}{|c|c|c|c|c|c|}
\hline \multirow[b]{2}{*}{ variable } & & \multicolumn{2}{|c|}{ HBS } & \multicolumn{2}{|c|}{ RLMS } \\
\hline & & & & & \\
\hline & & mean & sd & mean & sd \\
\hline & Personal characteristics: & & & & \\
\hline age & & 41.19 & 17.67 & 40.92 & 18.53 \\
\hline gender & & 1.58 & 0.49 & 1.56 & 0.50 \\
\hline & 1 male & $42.41 \%$ & & $43.74 \%$ & \\
\hline & 2 female & $57.59 \%$ & & $56.26 \%$ & \\
\hline skilled & get educatoin or training after high school & 0.57 & 0.50 & 0.65 & 0.48 \\
\hline & 0 unskilled & $43.03 \%$ & & $35.32 \%$ & \\
\hline & 1 skilled & $56.97 \%$ & & $64.68 \%$ & \\
\hline headhh & Head of the household & 0.43 & 0.49 & 0.37 & 0.48 \\
\hline & Household characteristics: & & & & \\
\hline famsize & Family size & 3.32 & 1.36 & 3.53 & 1.63 \\
\hline inincsize & \# of members who has source of income & 2.22 & 0.88 & 2.49 & 1.39 \\
\hline & & & & & \\
\hline & Geographical characteristics: & & & & \\
\hline region & & 3.93 & 2.17 & 3.67 & 1.94 \\
\hline & 0 - Moscow and St. Petersburg & $4.26 \%$ & & $5.22 \%$ & \\
\hline & 1 - Northern and North Western & $9.13 \%$ & & $7.25 \%$ & \\
\hline & 2 - Central and Central Black-Earth & $18.39 \%$ & & $18.51 \%$ & \\
\hline & 3 - Volga-Vyatski and Volga Basin & $16.11 \%$ & & $18.67 \%$ & \\
\hline & 4 - North Caucasian & $11.86 \%$ & & $14.98 \%$ & \\
\hline & 5 - Ural & $10.62 \%$ & & $15.07 \%$ & \\
\hline & 6 - Western Siberian & $9.54 \%$ & & $10.2 \%$ & \\
\hline & 7 - Easten Siberian and Far Eastern & $20.08 \%$ & & $10.1 \%$ & \\
\hline rural & & 0.34 & 0.47 & 0.37 & 0.48 \\
\hline & & $65.65 \%$ & & $63.44 \%$ & \\
\hline & & $34.35 \%$ & & $36.56 \%$ & \\
\hline & Occupation and income: & & & & \\
\hline prim_oc & first source of income & 2.36 & 1.60 & 2.69 & 1.69 \\
\hline & 1 worker & $54.04 \%$ & & $43.93 \%$ & \\
\hline & 2 entrepreneur & $0.44 \%$ & & $2.35 \%$ & \\
\hline & 3 pensioner & $19.52 \%$ & & $24.15 \%$ & \\
\hline & 4 unemployed & $7.94 \%$ & & $0.28 \%$ & \\
\hline & 5 other & $18.06 \%$ & & $29.29 \%$ & \\
\hline sec_oc & second source of income & 0.04 & 0.31 & 0.16 & 0.64 \\
\hline & 0 none & $98.08 \%$ & & $93.01 \%$ & \\
\hline & 1 worker & $0.81 \%$ & & $2.31 \%$ & \\
\hline & 2 entrepreneur & $0.23 \%$ & & $0.24 \%$ & \\
\hline & 3 working pensioner & $0.88 \%$ & & $4.44 \%$ & \\
\hline oth_oc & additional source of income & 0.00 & 0.03 & 0.09 & 0.29 \\
\hline & 0 none & $99.91 \%$ & & $91.05 \%$ & \\
\hline & 1 yes & $0.09 \%$ & & $8.95 \%$ & \\
\hline & & & & & \\
\hline indinc & Individual income, rbs per 3 month & & & 3285 & 5701 \\
\hline hhinc & Household income, rbs per 3 month & 12611 & 10451 & 10642 & 13415 \\
\hline
\end{tabular}


Table 2. Individual shares of the household income

\begin{tabular}{|c|c|c|}
\hline Members with sources of income & Head of the household & Other members of household \\
\hline 1 & 1 & 0 \\
\hline 2 & 0.53 & 0.47 \\
\hline 3 & 0.4 & 0.6 \\
\hline 4 & 0.31 & 0.69 \\
\hline 5 or more & 0.25 & 0.75 \\
\hline
\end{tabular}

\begin{tabular}{|c|c|c|c|c|}
\hline Table 3. Logit regression. & & & & \\
\hline Income quintile & 2 & 3 & 4 & 5 \\
\hline Dependent variable & \multicolumn{4}{|c|}{ Labor share of income } \\
\hline Individual characteristics & & & & \\
\hline \multirow[t]{2}{*}{ indinc } & -0.001 & 0 & -0.001 & -0.0008 \\
\hline & [0.88] & {$[0.19]$} & {$[6.34]^{\star *}$} & {$[8.96]^{\star \star}$} \\
\hline \multirow[t]{2}{*}{ gender } & -0.145 & 0.421 & -0.262 & -0.117 \\
\hline & {$[0.23]$} & {$[0.66]$} & [1.17] & {$[0.89]$} \\
\hline \multirow[t]{2}{*}{ age } & 0.05 & -0.009 & 0.009 & -0.001 \\
\hline & [1.48] & [0.32] & [0.79] & {$[0.19]$} \\
\hline \multirow[t]{2}{*}{ skilled } & 0.195 & 0.884 & 1.201 & 0.382 \\
\hline & [0.24] & [1.40] & {$[4.92]^{\star *}$} & {$[2.11]^{\star}$} \\
\hline \multirow[t]{2}{*}{ headhh } & -0.723 & -0.455 & -0.141 & -0.007 \\
\hline & [1.09] & {$[0.75]$} & [0.62] & {$[0.06]$} \\
\hline \multicolumn{5}{|l|}{ Primary occupation } \\
\hline \multirow[t]{2}{*}{ worker } & -19.47 & -0.91 & -2.866 & -3.523 \\
\hline & [0.01] & [0.74] & {$[2.73]^{\star *}$} & {$[5.31]^{\star \star}$} \\
\hline \multirow[t]{2}{*}{ entrep } & -22.245 & 1.073 & -3.503 & -3.551 \\
\hline & [0.02] & [0.22] & {$[3.08]^{\star \star}$} & {$[5.11]^{\star \star}$} \\
\hline \multirow[t]{2}{*}{ pensioner } & -3.298 & 16.325 & 12.994 & 11.832 \\
\hline & {$[0.00]$} & {$[0.05]$} & [0.02] & {$[0.02]$} \\
\hline \multirow[t]{2}{*}{ unemployed } & -2.63 & 16.372 & 13.154 & 12.403 \\
\hline & {$[0.00]$} & {$[0.00]$} & {$[0.00]$} & {$[0.01]$} \\
\hline Secondary occupation & & & & \\
\hline
\end{tabular}




\begin{tabular}{|c|c|c|c|c|}
\hline worker2 & -2.362 & -1.57 & -0.624 & 0.091 \\
\hline & {$[2.00]^{*}$} & [1.87] & {$[1.50]$} & {$[0.35]$} \\
\hline \multirow[t]{2}{*}{ entrep2 } & 17.304 & 14.651 & -2.138 & 0.244 \\
\hline & {$[0.00]$} & {$[0.00]$} & {$[2.77]^{\star \star}$} & {$[0.34]$} \\
\hline \multirow[t]{2}{*}{ pensioner2 } & 0.261 & 16.679 & 0.764 & 0.952 \\
\hline & {$[0.14]$} & {$[0.01]$} & {$[1.62]$} & {$[4.02]^{* *}$} \\
\hline \multicolumn{5}{|l|}{ Other occupation } \\
\hline \multirow[t]{2}{*}{ worker3 } & -2.621 & -0.888 & -0.525 & 0.247 \\
\hline & {$[4.03]^{* *}$} & [0.97] & {$[1.47]$} & {$[1.03]$} \\
\hline \multicolumn{5}{|l|}{ Geographical characteristics } \\
\hline \multirow[t]{2}{*}{ rural } & -0.308 & 0.85 & 0.35 & 0.019 \\
\hline & {$[0.47]$} & [1.15] & [1.23] & [0.11] \\
\hline \multirow[t]{2}{*}{ north } & 18.027 & 3.222 & -1.398 & -0.183 \\
\hline & {$[0.02]$} & {$[0.96]$} & {$[1.55]$} & {$[0.51]$} \\
\hline \multirow[t]{2}{*}{ center } & 2.431 & 1.476 & -0.988 & -1.025 \\
\hline & {$[2.00]^{*}$} & {$[1.17]$} & [1.18] & {$[3.19]^{\star *}$} \\
\hline \multirow[t]{2}{*}{ volga } & 3.191 & 1.638 & -1.967 & -1.31 \\
\hline & {$[2.43]^{*}$} & [1.26] & {$[2.37]^{*}$} & {$[3.89]^{* *}$} \\
\hline \multirow[t]{2}{*}{ caucas } & 1.868 & 1.021 & -2.025 & -1.445 \\
\hline & {$[1.56]$} & {$[0.76]$} & {$[2.37]^{*}$} & {$[4.03]^{* *}$} \\
\hline \multirow[t]{2}{*}{ ural } & 1.724 & 1.879 & -1.625 & -1.262 \\
\hline & {$[1.59]$} & [1.37] & [1.96] & {$[3.90]^{* *}$} \\
\hline \multirow[t]{2}{*}{ syberia } & 1.671 & 1.655 & -0.709 & -0.938 \\
\hline & {$[1.40]$} & [1.13] & {$[0.79]$} & {$[2.71]^{\star *}$} \\
\hline \multirow[t]{2}{*}{ far_east } & 4.272 & 0.741 & -0.999 & -1.302 \\
\hline & {$[1.75]$} & {$[0.55]$} & {$[1.13]$} & {$[3.93]^{* *}$} \\
\hline Observations & 1582 & 1681 & 1646 & 1436 \\
\hline $\begin{array}{r}\text { Absolute value of } z \text { statistics in } \\
\text { parentheses }\end{array}$ & & & & \\
\hline${ }^{*}$ significant at $5 \% ;{ }^{* *}$ significant at $1 \%$ & & & & \\
\hline
\end{tabular}




\begin{tabular}{|r|r|r|r|r|r|r|}
\hline \multicolumn{6}{|c|}{ Table 4. Factor shares by income deciles* } \\
\hline $\begin{array}{r}\text { Income } \\
\text { decile }\end{array}$ & \multicolumn{2}{|c|}{ Skilled labor } & \multicolumn{2}{|c|}{ Unskilled labor } & \multicolumn{2}{c|}{ Capital } \\
\hline & RLMS & HBS & \multicolumn{1}{l}{ RLMS } & HBS & RLMS & HBS \\
\hline 1 & 0.537 & 0.460 & 0.437 & 0.535 & 0.026 & 0.004 \\
\hline 2 & 0.621 & 0.556 & 0.361 & 0.431 & 0.018 & 0.013 \\
\hline 3 & 0.651 & 0.566 & 0.330 & 0.385 & 0.019 & 0.049 \\
\hline 4 & 0.693 & 0.585 & 0.286 & 0.346 & 0.022 & 0.069 \\
\hline 5 & 0.688 & 0.621 & 0.265 & 0.314 & 0.047 & 0.065 \\
\hline 6 & 0.690 & 0.617 & 0.209 & 0.287 & 0.100 & 0.096 \\
\hline 7 & 0.682 & 0.601 & 0.180 & 0.238 & 0.138 & 0.162 \\
\hline 8 & 0.657 & 0.552 & 0.143 & 0.215 & 0.200 & 0.233 \\
\hline 9 & 0.589 & 0.538 & 0.128 & 0.182 & 0.284 & 0.279 \\
\hline 10 & 0.483 & 0.458 & 0.081 & 0.135 & 0.436 & 0.406 \\
\hline Total & 0.629 & 0.555 & 0.243 & 0.307 & 0.128 & 0.138 \\
\hline${ }^{*}$ HBS shares based on the regression results & & & \\
\hline
\end{tabular}

\begin{tabular}{|r|r|r|r|r|r|r|}
\hline \multicolumn{7}{|c|}{ Table 5. Factor shares by income deciles* } \\
\hline $\begin{array}{r}\text { Income } \\
\text { decile }\end{array}$ & \multicolumn{2}{|c|}{ Skilled labor } & \multicolumn{2}{l}{ Unskilled labor } & \multicolumn{2}{|c|}{ Capital } \\
\hline & \multicolumn{1}{|c|}{ RLMS } & HBS & RLMS & HBS & RLMS & HBS \\
\hline 1 & 0.537 & 0.494 & 0.437 & 0.433 & 0.026 & 0.073 \\
\hline 2 & 0.621 & 0.558 & 0.361 & 0.343 & 0.018 & 0.099 \\
\hline 3 & 0.651 & 0.577 & 0.330 & 0.308 & 0.019 & 0.115 \\
\hline 4 & 0.693 & 0.607 & 0.286 & 0.270 & 0.022 & 0.123 \\
\hline 5 & 0.688 & 0.592 & 0.265 & 0.260 & 0.047 & 0.148 \\
\hline 6 & 0.690 & 0.610 & 0.209 & 0.238 & 0.100 & 0.153 \\
\hline 7 & 0.682 & 0.599 & 0.180 & 0.230 & 0.138 & 0.172 \\
\hline 8 & 0.657 & 0.609 & 0.143 & 0.202 & 0.200 & 0.189 \\
\hline 9 & 0.589 & 0.548 & 0.128 & 0.160 & 0.284 & 0.292 \\
\hline 10 & 0.483 & 0.482 & 0.081 & 0.132 & 0.436 & 0.385 \\
\hline Total & 0.629 & 0.568 & 0.243 & 0.258 & 0.128 & 0.175 \\
\hline
\end{tabular}

